\title{
THE DEVELOPMENT OF PEPTIDERGIC NEURONS IN THE FOREGUT OF THE CHICK ${ }^{1}$
}

\author{
MILES L. EPSTEIN, ${ }^{2}$ JAN HUDIS, AND JUNE L. DAHL* \\ Departments of Anatomy and *Pharmacology, University of Wisconsin Medical School, Madison, Wisconsin 53706
}

Received April 2, 1982; Revised June 7, 1983; Accepted June 13, 1983

\begin{abstract}
We have used antisera specifically directed against Met-enkephalin (met-ENK), somatostatin (SOM), substance P (SP), and vasoactive intestinal peptide (VIP), to study the development of neurons containing these peptides in the foregut of the chick. All four peptides were detected early in ontogeny, at 4 to 9 days of incubation (d.i.), and were localized primarily to cell bodies in the primitive myenteric plexus. There were differences in the times at which they were first detected and in the sequence of their appearance in the proventriculus, gizzard, and duodenum.

The differentiation of these peptidergic neurons in the duodenum was examined in some detail. Cell bodies containing these peptides were first detected in the primitive myenteric plexus at 5 to 7 d.i. and increased in number from 7 to 11 d.i. Processes containing varicosities became prominent between 11 and 13 d.i. VIP was the first of the peptides to appear in the submucosal plexus and was found in more proximal regions of the duodenum at 5 d.i. Shortly thereafter, SOM- and SPcontaining cell bodies were seen; met-ENK-containing cell bodies were never detected in the submucosal plexus. At 13 d.i., the circular smooth muscle contained a number of VIP-immunoreactive and a smaller number of SOM-immunoreactive processes. met-ENK- and SP-immunoreactive processes appeared in the circular smooth muscle between 17 and 21 d.i.; VIP- and SP-immunoreactive processes appeared in the mucosal plexus at 17 to $21 \mathrm{~d}$.i.

Our results suggest that neuropeptides appear very early in the ontogeny of enteric neurons, at the same time or even before cholinergic and serotonergic neurons express their phenotypes. These findings argue against a sequential developmental order in which peptidergic neurons appear after those containing acetylcholine and serotonin.
\end{abstract}

The vertebrate gut contains a variety of molecules thought to act as neurotransmitters. These include a number of peptides which have been localized to neurons intrinsic to the mammalian (Schultzberg et al., 1978; Furness and Costa, 1980; Burnstock, 1981; Gershon, 1981; Malmfors et al., 1981; Polak and Bloom, 1981) and avian (Alumets et al., 1978; Sundler et al., 1979; Fontaine-Perus et al., 1981; Saffrey et al., 1982) gut. The distribution of these peptides along the length of the mammalian gastrointestinal tract has been described by extensive immunocytochemical studies by Furness et al. (1981) and Schultzberg et al. (1980). Their observations

\footnotetext{
' This work was supported by National Institutes of Health Grant AM 32978 (M. L. E.) and by funds provided by the Graduate School of the University of Wisconsin (J. L. D.). We are grateful to Drs. Robert Elde, Julia Polak, Ray Ho, and John Wood for their generous gifts of antisera. We wish to thank Dr. Edward Schultz for his insight and generosity, and Ms. Sue Leonard for typing the manuscript.

${ }^{2}$ To whom correspondence should be addressed, at Department of Anatomy, University of Wisconsin, Madison, WI 53706.
}

and the results of physiological studies (Gintzler, 1980; Brodin et al., 1981; Holzer et al., 1981) suggest that peptidergic neurons play a role in regulating the motility of the gastrointestinal tract, but the precise way in which this is accomplished is not known.

The variety of peptides in the enteric nervous system is of interest from a developmental standpoint. Although it is known that the intrinsic neurons of the gut develop from the neural crest (LeDouarin and Teillet, 1973), the mechanisms which regulate the expression of the diverse peptide phenotypes have not been elucidated. As part of the initial phase of an investigation aimed at understanding the factors which control the expression of peptidergic neurons in the gut, we have used immunocytochemistry to study the pattern of development of specific populations of peptide-containing neurons in the foregut of the chick. In particular, we have determined the time of appearance, differentiation, and arrangement of enteric neurons which contain Met-enkephalin (metENK), somatostatin (SOM), substance P (SP), and vasoactive intestinal peptide (VIP). 
To achieve these goals, we have chosen to study the avian enteric nervous system because chick embryo development is easily staged, can be altered by drugs, and can be subjected to other tissue influences through physical manipulation. Furthermore, the development of enteric cholinergic (Smith et al., 1977) and serotonergic (Epstein et al., 1980; Gershon et al., 1980) neurons has been characterized so that comparisons can be made between the ontogeny of neurons containing small molecule (classical) neurotransmitters and those containing neuropeptides.

\section{Materials and Methods}

Fixation. The methods used were essentially as described previously (Fpstein et al., 1981). Fertilized White Leghorn (Gallus gallus L.) eggs were incubated at $38.5^{\circ}$ $\pm 0.2^{\circ} \mathrm{C}$ for various times; gastrointestinal tracts were removed from the embryos and fixed in freshly made $4 \%$ paraformaldehyde in $0.1 \mathrm{~m}$ phosphate buffer, $\mathrm{pH} 7.3$, for 6 to $12 \mathrm{hr}$ at $4^{\circ} \mathrm{C}$. Pieces of gastrointestinal tract from newly hatched chickens were similarly treated. After fixation, tissues were washed overnight in $0.1 \mathrm{M}$ phosphate buffer containing $5 \%$ sucrose. In some experiments, tissues were fixed in recrystallized $0.4 \% p$-benzoquinone in phosphate-buffered saline (PBS) for $3 \mathrm{hr}$ at $4^{\circ} \mathrm{C}$ (Fontaine-Perus et al., 1981).

Peptide staining. Fixed tissues were frozen in Tissue Tek and cut at 10 to $20 \mu \mathrm{m}$ on a cryostat. The sections were placed on gelatin-coated slides, washed with PBS, and incubated overnight at $4^{\circ} \mathrm{C}$ with primary antiserum in a solution of $\mathrm{PBS}, 0.3 \%$ Triton $\mathrm{X}-100$, and $0.05 \%$ sodium azide. Antisera directed against the various peptides were obtained from the following sources: met-ENK and leu-ENK, Dr. Robert Elde, University of Minnesota, Minneapolis, MN; SOM, Immunonuclear Corp., Stillwater, MN; VIP, Dr. Julia Polak, Hammersmith Hospital, London, UK; SP, Dr. Ray Ho, Ohio State University, Columbus, $\mathrm{OH}$. In addition, a monoclonal SP antibody was purchased from Accurate Chemical Co., Westbury, NY. All antisera were used at dilutions of 1:300 to 1:3000.

The primary antisera were visualized by the immunofluorescence method of Coons (1958) or the peroxidaseantiperoxidase (PAP) technique of Sternberger (1979) as described previously (Epstein et al., 1981). Because the monoclonal antibody directed against SP was raised in a rat-mouse hybridoma, special procedures were necessary for visualization of this antiserum with PAP. Specifically, the sections were incubated sequentially at room temperature for $1 \mathrm{hr}$ with rabbit anti-rat antiserum $(1: 20$, Accurate Chemical Co.), pig anti-rabbit antiserum (1:20, Dako Corp., Santa Barbara, CA), and finally, PAP antiserum (1:50, Dako).

Sections from the proventriculus, gizzard, and duodenum from embryos of different ages were placed routinely on the same slide and thus were exposed to the same antiserum. Thus, differences in immunoreactivity observed between different ages were not a result of variations in processing.

Peptide staining controls. Control sections were incubated with antisera absorbed with an excess of the corresponding peptide (5 $\mathrm{nM}$ met-ENK, SP, and SOM, or $1.2 \mathrm{nM}$ VIP). No immunoreactivity was detected in sec- tions of duodenum from embryos of different ages which had been incubated with these different preabsorbed antisera. In addition, the cross-reactivity of each antiserum with the other peptides was checked by incubating sections with antisera absorbed with the other three peptides (10 mM met-ENK, SP, or SOM, and $2 \mathrm{mM}$ VIP). Because the primary antisera may bind to as yet unidentified substances, the immune controls do not fully guard against false-positive results. Nevertheless, we have for the sake of simplicity referred to met-ENK, SOM, SP, and VIP immunoreactivity (IR) instead of the more precise terms met-ENK-like, SOM-like, SP-like, and VIP-like immunoreactivity.

Coincident staining for neuropeptides and neurofilament protein. The procedure for coincident staining was similar to that described by Erichsen et al. (1982). A monoclonal antibody which recognizes the 2-kilodalton neurofilament protein was kindly provided by Dr. John N. Wood, Wellcome Research Laboratories, Kent, UK, and was used at a dilution of 1:1000. Tissue sections were incubated overnight in a mixture of peptide (either VIP, leu-ENK, or SOM) and neurofilament protein antisera, washed, and subsequently incubated in a mixture of goat anti-rabbit IgG conjugated to fluorescein isothiocyanate (FITC) (Miles Laboratories, Elkhart, IN) and goat antimouse IgG conjugated to tetramethylrhodamine isothiocyanate (TRITC) (N. L. Cappel Laboratories, West Chester, PA).

Tissues were examined with Olympus epifluorescence optics (BH-RFL-W) using the appropriate filter combinations for visualization of FITC and TRITC, respectively. To ensure that the optics separated the fluorophore signals, slides were incubated in neurofilament antibody alone and then in TRITC-conjugated second antibody. The TRITC was visualized with the appropriate filter combination; no fluorescence was observed with the FITC filter combination. Film exposures of varying duration were made of the TRITC fluorescence using the FITC filter combination; the signals were found to be at or below background, thus confirming the visual observations. The converse experiments were conducted so that FITC was observed with a TRITC filter combination. No fluorescence was observed in this situation. As additional controls, sections were incubated with $(a)$ rabbit anti-peptide antisera followed by TRITC antimouse antisera, $(b)$ mouse anti-neurofilament antisera followed by FITC anti-rabbit antisera, or (c) control ascites from hybridomas raised in our laboratory followed by TRITC anti-mouse antisera. In all of the above controls, no fluorescence was observed.

\section{Results}

Although essentially identical results were obtained whether the primary antisera were visualized with the immunofluorescence method or with the PAP technique, documentation of the presence of immunoreactivity was easier with PAP; therefore, those are the results presented in this paper. The number of embryos examined at different stages of development and the number in which specific peptide immunoreactivity was detected in the different regions of the foregut are indicated in Table I. A simplified representation of the developmental 
TABLE I

Frequency of appearance of peptide immunoreactivity in chick gut at various developmental ages

\begin{tabular}{|c|c|c|c|c|}
\hline & Age & Proventriculus & Gizzard & Duodenum \\
\hline \multirow[t]{9}{*}{ met-ENK } & 4 & $0 / 5^{a}$ & $1 / 11$ & $0 / 5$ \\
\hline & 5 & $0 / 9$ & $10 / 10$ & $3 / 6$ \\
\hline & 6 & $0 / 6$ & $7 / 7$ & $8 / 10$ \\
\hline & 7 & $2 / 6$ & $6 / 6$ & $12 / 12$ \\
\hline & 9 & $4 / 8$ & $6 / 6$ & $12 / 12$ \\
\hline & 11 & $3 / 3$ & $3 / 4$ & $8 / 8$ \\
\hline & 13 & $3 / 3$ & $3 / 3$ & $9 / 9$ \\
\hline & 17 & $6 / 7$ & $3 / 3$ & $12 / 12$ \\
\hline & $\mathrm{NH}^{b}$ & $5 / 5$ & $5 / 5$ & $10 / 10$ \\
\hline \multirow[t]{9}{*}{ SP } & 4 & $0 / 5$ & $0 / 8$ & $0 / 6$ \\
\hline & 5 & $1 / 8$ & $2 / 9$ & $0 / 5$ \\
\hline & 6 & $3 / 7$ & $4 / 7$ & $4 / 10$ \\
\hline & 7 & $3 / 7$ & $7 / 10$ & $8 / 16$ \\
\hline & 9 & $9 / 10$ & $6 / 9$ & $10 / 12$ \\
\hline & 11 & $2 / 3$ & $3 / 3$ & $9 / 9$ \\
\hline & 13 & $3 / 3$ & $5 / 5$ & $7 / 7$ \\
\hline & 17 & $4 / 4$ & $3 / 3$ & $6 / 6$ \\
\hline & $\mathrm{NH}$ & $5 / 5$ & $4 / 5$ & $11 / 11$ \\
\hline \multirow[t]{9}{*}{ VIP } & 4 & $0 / 5$ & $0 / 6$ & $0 / 6$ \\
\hline & 5 & $7 / 8$ & $8 / 11$ & $3 / 4$ \\
\hline & 6 & $10 / 10$ & $9 / 11$ & $5 / 8$ \\
\hline & 7 & $8 / 8$ & $7 / 7$ & $8 / 10$ \\
\hline & 9 & $6 / 6$ & $8 / 8$ & $8 / 9$ \\
\hline & 11 & $4 / 4$ & $3 / 3$ & $7 / 9$ \\
\hline & 13 & $3 / 3$ & $3 / 3$ & $7 / 7$ \\
\hline & 17 & $5 / 5$ & $3 / 3$ & $8 / 8$ \\
\hline & $\mathrm{NH}$ & $4 / 4$ & $3 / 4$ & $10 / 10$ \\
\hline \multirow[t]{9}{*}{ SOM } & 4 & $0 / 5$ & $8 / 9$ & $0 / 5$ \\
\hline & 5 & $0 / 9$ & $11 / 12$ & $0 / 7$ \\
\hline & 6 & $0 / 8$ & $8 / 11$ & $0 / 10$ \\
\hline & 7 & $0 / 6$ & $8 / 8$ & $5 / 16$ \\
\hline & 9 & $0 / 7$ & $6 / 6$ & $7 / 9$ \\
\hline & 11 & $1 / 8$ & $4 / 4$ & $8 / 9$ \\
\hline & 13 & $1 / 4$ & $3 / 3$ & $9 / 9$ \\
\hline & 17 & $2 / 7$ & $4 / 4$ & $6 / 6$ \\
\hline & $\mathrm{NH}$ & $3 / 6$ & $4 / 4$ & $6 / 6$ \\
\hline
\end{tabular}

${ }^{a}$ Number of embryos showing immunoreactivity per total number of embryos examined.

${ }^{b} \mathrm{NH}$, newly hatched.

changes in the distribution and the relative amount of met-ENK-, SOM-, SP-, and VIP-IR in the proventriculus, gizzard, and duodenum is presented in Table II. The results in the table and those described below are based on visual observations of the immunoreactivity and thus represent a qualitative description of changes.

Proventriculus. The proventriculus, the secretory portion of the avian stomach, is essentially a tube which at early stages of development ( 5 to 7 days of incubation (d.i.)) consists of concentric layers of serosa, smooth muscle precursors, mesenchyme, and mucosa. VIP-IR was detected in this structure at 5 to 6 d.i. and was located around its circumference primarily between the layer of smooth muscle precursors and the serosa in the region of the developing myenteric plexus (Fig. $1 A$ ). Although most of the immunoreactivity was confined to cell bodies, small amounts were found in short processes (Fig. $1 B$ ). By 9 to 11 d.i., there appeared to be a greater number of cell bodies; fibers extended across the smooth muscle into the submucosa. At 13 d.i. there was an
TABLE II

A simplified representation of the changes in the amount and distribution of met-ENK-SOM-, SP-, and VIP-IR in the proventriculus, gizzard, and duodenum of the developing chick
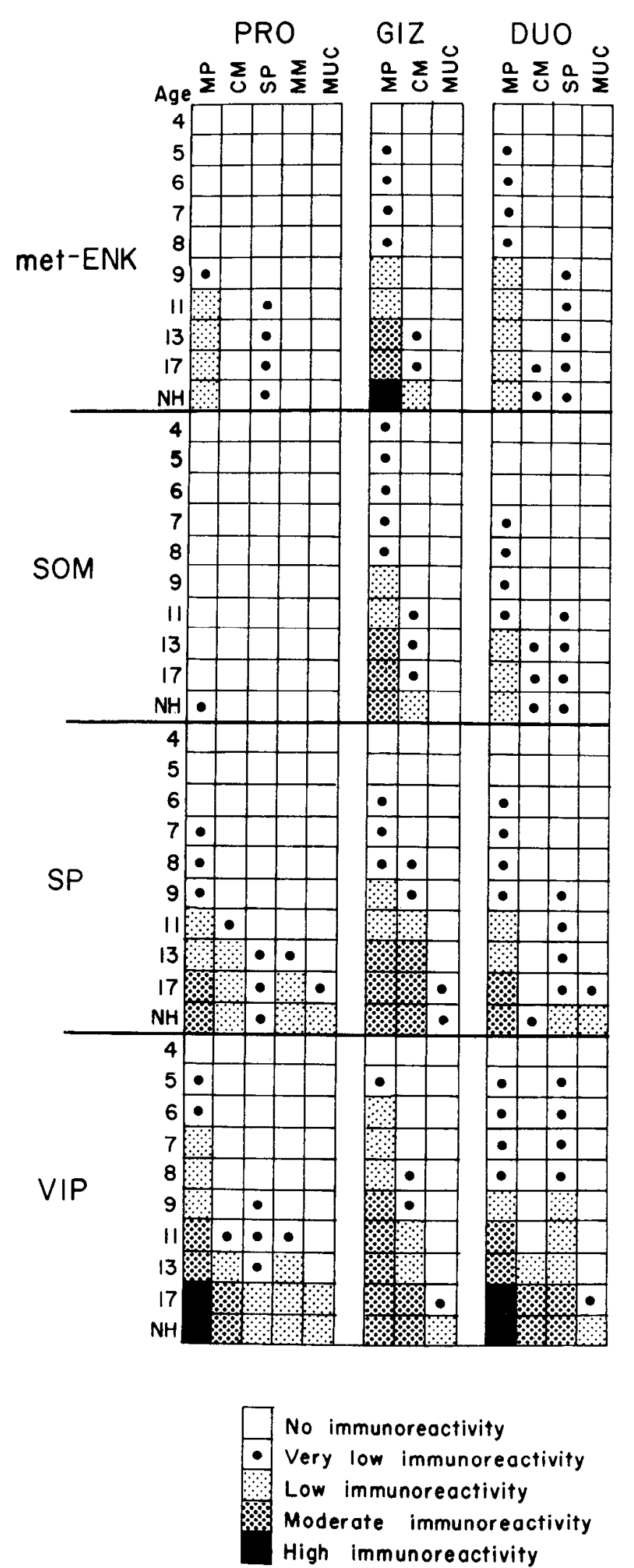

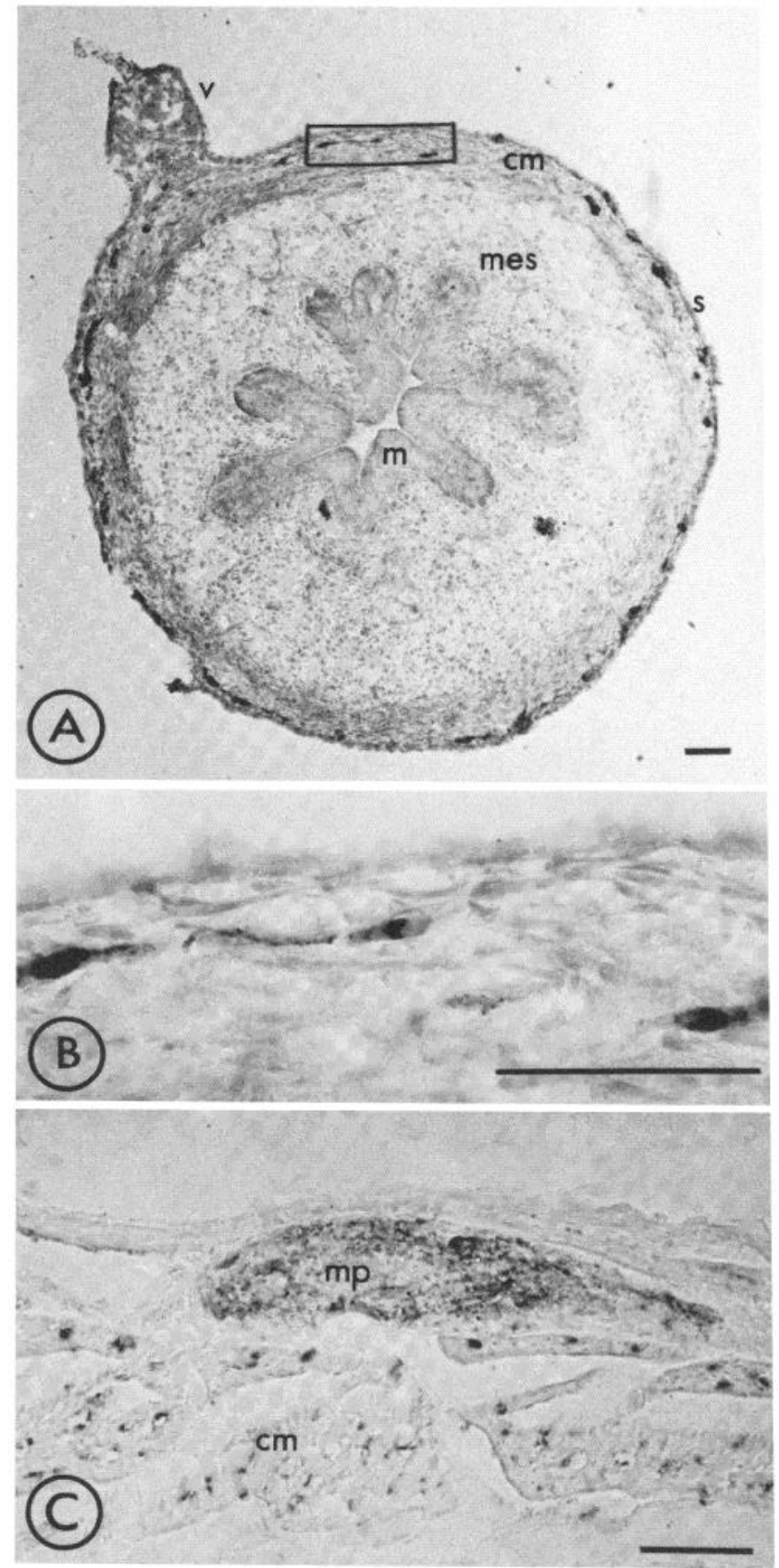

Figure 1. Micrographs of proventriculus from 6-day embryonic and newly hatched chick showing VIP-IR. A, Transverse section from 6-day chick embryo. VIP-IR is located around the circumference between the layer of smooth muscle precursors $(\mathrm{cm})$ and the serosa $(\mathrm{s})$. mes, mesenchyme $m$, mucosa. A portion of the developing vagus nerve $(v)$ is shown. Scale bar, $50 \mu \mathrm{m}$ in $A, B$, and $C$. $B$, The enclosed portion of $A$ at higher magnification. VIP-IR is found within solitary cell bodies and their short processes. $C$, Longitudinal section from newly hatched chick. VIP-IR is found in the myenteric plexus $(m p)$ and in circular smooth muscle $(\mathrm{cm})$.

extensive network of fibers within the circular smooth muscle and muscularis mucosae. Immunoreactive fibers were found around the glandular epithelium and in the lamina propria of the villi at 17 d.i. (Table II).

In neither these experiments nor the ones reported subsequently were we able to distinguish intrinsic from extrinsic fibers. However, when pieces of 9-day embryonic foregut were grown on chorioallantoic membrane of host chicks for 6 days, we found essentially the same density of VIP and ENK fibers as we did in sections of gut taken from normal embryos. These preliminary findings suggest that most of the fibers we describe in this work are intrinsic.

SP-IR was detected in a minority of specimens from 5- to 8-day-old embryos, but was found with regularity at 9 d.i. (Table I). Before 9 to 11 d.i. the intensity of staining was light. Immunoreactivity was localized in the primitive myenteric plexus until 11 to 13 d.i., after which immunoreactive fibers were also found in the circular smooth muscle, submucosal plexus, and muscularis mucosae. At the time of hatching, immunoreactivity was concentrated in the myenteric plexus, smooth muscle, muscularis mucosae, and mucosa (Table II).

In comparison to VIP, a few met-ENK-immunoreactive cells were found in the myenteric plexus at $9 \mathrm{~d}$.i. The amount of immunoreactivity had increased by 11 to 13 d.i. and was found in the myenteric and submucosal plexuses. At the time of hatching a small amount of immunoreactivity was found in fibers located in the lamina propria of the glands of the mucosa.

SOM-IR cell bodies were seen on only one occasionin the myenteric plexus of an 11-day embryo. At later stages, a very small number of fibers (1 to 3 ) were observed (Table II). Clearly the amount of SOM-IR in the proventriculus is very small compared to that of the other peptides. In contrast, the junction of the proventriculus and gizzard where no glandular cells are present contains large amounts of SOM-IR.

Gizzard. The gizzard, the muscular portion of the avian stomach, is a tubular structure. The mesenchyme of the gizzard proliferates to form the thick muscle layers characteristic of this organ. The myenteric plexus, after the loss of the outer longitudinal smooth muscle at $10 \mathrm{~d}$.i. (Bennett and Cobb, 1969), is located just below the serosa and in ganglionated networks of nerve fibers within the muscular layers. No submucosal plexus is present.

In contrast to our observations in the proventriculus, all four peptides were found at 4 to 6 d.i. in the gizzard. SOM-IR cells were first detected at 4 d.i. near the serosa of this structure. By 6 d.i. the immunoreactive cells had increased in number and were found in islands of neural elements located in the putative myenteric plexus at the periphery of the developing layer of smooth muscle (Fig. $2, A$ and $B$ ). met-ENK-IR was first detected at 5 d.i. in cell bodies; more immunoreactive cells were present at 6 d.i. (Fig. 2, $C$ and $D$ ) with the same pattern of distribution as was observed for SOM-IR. VIP-IR (Fig. 2, $E$ to $G$ ) and SP-IR (Fig. 2, $H$ to $J$ ) both appeared in the primitive myenteric plexus at 5 to 6 d.i. A small number of SP-IR fibers were also detected at this time (Fig. $2 J$ ).

In the time period between 7 and 13 d.i. there appeared to be an increase in the number of immunoreactive fibers and cells within the smooth muscle layer. At 17 d.i., fibers containing VIP- and SP-IR were much more abundant in the smooth muscle than were those containing SOM- and met-ENK-IR. At this time, fibers containing VIP- and SP-IR were observed in the mucosa. At the 
time of hatching, VIP- and SP-IR were distributed in the myenteric plexus, smooth muscle, and mucosa, whereas SOM- and met-ENK-IR were found in the myenteric plexus and smooth muscle (Table II).

Duodenum. At 5 to $7 \mathrm{~d}$.i. the duodenum consists of a tube, covered on its outer surface by serosa and containing concentric layers of smooth muscle precursors, mesenchyme, and mucosa.

met-ENK. met-ENK-IR was found at 5 to 6 d.i. in cell bodies along the length of the duodenum in the region of the primitive myenteric plexus (Fig. $3, A$ to $C$ ). As is also apparent in Figure $2 C$, immunoreactive cell bodies were observed in the duodenal-gizzard junction. At 9 d.i., metENK-IR was found around the entire circumference of the duodenum (Fig. $4 A$ ), still localized to cell bodies in the myenteric plexus although processes were occasionally visible (Fig. 5A). At 11 d.i. more processes were present, but most of the immunoreactivity was still in cell bodies. By 13 d.i. the diameter of the duodenum and the thickness of the smooth muscle layer have increased in size. met-ENK-IR in the myenteric plexus was now localized in discrete areas (Fig. $4 E$ ). In addition, the distribution of the immunoreactivity had changed, and many stained processes with varicosities were observed in the myenteric plexus as well as a small number in the submucosal plexus (Fig. 5, $G$ and $H$ ). Between 17 and 21 d.i. (hatching), immunoreactive fibers appeared in the smooth muscle. At the time of hatching most of the metENK-IR was localized to varicosities in the myenteric plexus with smaller amounts in the submucosal plexus and circular smooth muscle (Figs. $4 I$ and $5 N$ ).

$S O M$. A few intensely stained SOM-IR cells were first detected in the duodenum at 7 d.i. (Fig. $3 D$ ). Clumps of cells were found at the base of the duodenal-pancreatic junction (Fig. 3, $D$ and $E$ ), and small groups of cells were scattered around the circumference of the duodenum in areas of presumptive myenteric plexus (Fig. $3 D$ ). Occasionally, an immunoreactive cell was found in the region of the submucosal plexus, separated from the myenteric plexus by a layer of developing smooth muscle (Fig. $3, D$ and $F$ ). By 9 d.i. the number of SOM-IR cells had increased but the intensity of staining was less than that observed with antisera directed against the other peptides (Figs. $4 B$ and $5 B$ ). A number of immunoreactive varicosities were seen in some regions of the myenteric plexus at 11 d.i. By 13 d.i., there was a greater amount of SOM-IR now visualized in varicose processes within both the myenteric and submucosal plexuses (Fig. $4 F$ ). A few processes, oriented parallel to the direction of the muscle fibers, were also found in the circular smooth muscle (Figs. $4 F$ and $5 I$ ). At 17 d.i. most of the immunoreactivity was confined to intensely stained varicosities in the myenteric plexus; an occasional cell body was also seen. Smaller amounts were found in the submucosal plexus and in fibers located within the circular smooth muscle. Immunoreactive cells were found in the mucosa at this time (not shown). This same pattern of immunoreactivity was also found in the duodenum of the newly hatched chick (Figs. $4 J$ and $5 O$ ).

$S P$. SP-IR was detected in the duodenum at 6 to 7 d.i. (Fig. 3, $G$ and $H$ ). By 9 d.i. the amount of immunoreactivity in the myenteric plexus had increased and a small amount was found occasionally in the submucosal plexus (Figs. $4 C$ and $5, C$ and $D$ ). By 11 d.i. there were a number of SP-IR cells in the submucosal plexus. At 13 d.i., processes within the myenteric plexus were visible (Figs. $4 G$ and $5, J$ and $K$ ); by 17 d.i. many processes were evident in the myenteric and submucosal plexuses and a few were found between the two. In the duodenum of the newly hatched chick most of the SP-IR was found in the myenteric plexus with smaller amounts in the submucosal plexus and circular smooth muscle (Figs. $4 \mathrm{~K}$ and $5 P)$. Occasional fibers could also be found in the mucosal plexus at the base of the glandular epithelium and inside the core of villi.

VIP. VIP-IR was first observed at 5 to 6 d.i. in cell bodies resident in the myenteric and submucosal plexuses located in the proximal portion of the duodenum (Fig. 3, $I$ to $K$ ). Most of the cells in the primitive submucosal plexus contained VIP-IR. In the distal region of the duodenum, immunoreactive cells were seen only in the myenteric plexus. It is not clear if the immunoreactive cells in the submucosal plexus migrated there before or after producing VIP. However, the presence of a small number of immunoreactive cells in the smooth muscle layer of 6 - to 11-day embryos (Fig. 6, $A$ and $B$ ) suggests that the cells migrate after acquiring VIP-IR. By 9 d.i. the number of stained cells (Figs. $4 D$ and $5, E$ and $F$ ) in both plexuses had increased and a few stained processes, passing directly across the smooth muscle and possibly connecting the two plexuses, were visualized (Fig. 5, $E$ and $F$ ). At 11 d.i. more of these "connecting" processes were apparent, and a small number of processes appeared to terminate in the smooth muscle layer (Fig. $6, A$ to $C$ ). By 13 d.i. the smooth muscle contained a number of VIP-IR fibers which were aligned parallel to the direction of the smooth muscle cells, and which appeared to originate mostly from the myenteric plexus (Figs. $4 H$ and $5 L$ ). At this time, VIP-IR was found in abundant varicosities in the myenteric plexus and mostly in cell bodies in the submucosal plexus (Figs. $4 \mathrm{H}$ and 5 , $L$ and $M$ ). However, by 17 d.i. varicosities were present in the submucosal plexus, although there were fewer than in the myenteric plexus. In addition, immunoreactive fibers were widely scattered in the circular smooth muscle. At the time of hatching, the pattern of VIP-IR in the gut wall was similar, but its density appeared greater than that found at $17 \mathrm{~d}$.i. Moreover, small amounts of immunoreactivity were also present in the mucosal plexus located in the lamina propria along the base of the mucosal epithelium (Figs. $4 L$ and $5 Q$ ) and in fibers found within the core of the villi (Table II).

In general, peptide immunoreactivity in the duodenum from the newly hatched chick was found predominantly in varicosities in contrast to the abundance of cell bodies visualized at earlier stages of development. As can be seen in Figures 4 and 5, all four peptides were found in the same ganglia of the myenteric plexus. On the basis of visual inspection, VIP-IR was the most abundant with immunoreactivity concentrated in the submucosal plexus; there were slightly smaller amounts in the myenteric plexus and in fibers in the smooth muscle and the mucosal plexus. SP-IR was the next most abundant with reaction product in the myenteric plexus; lesser amounts 

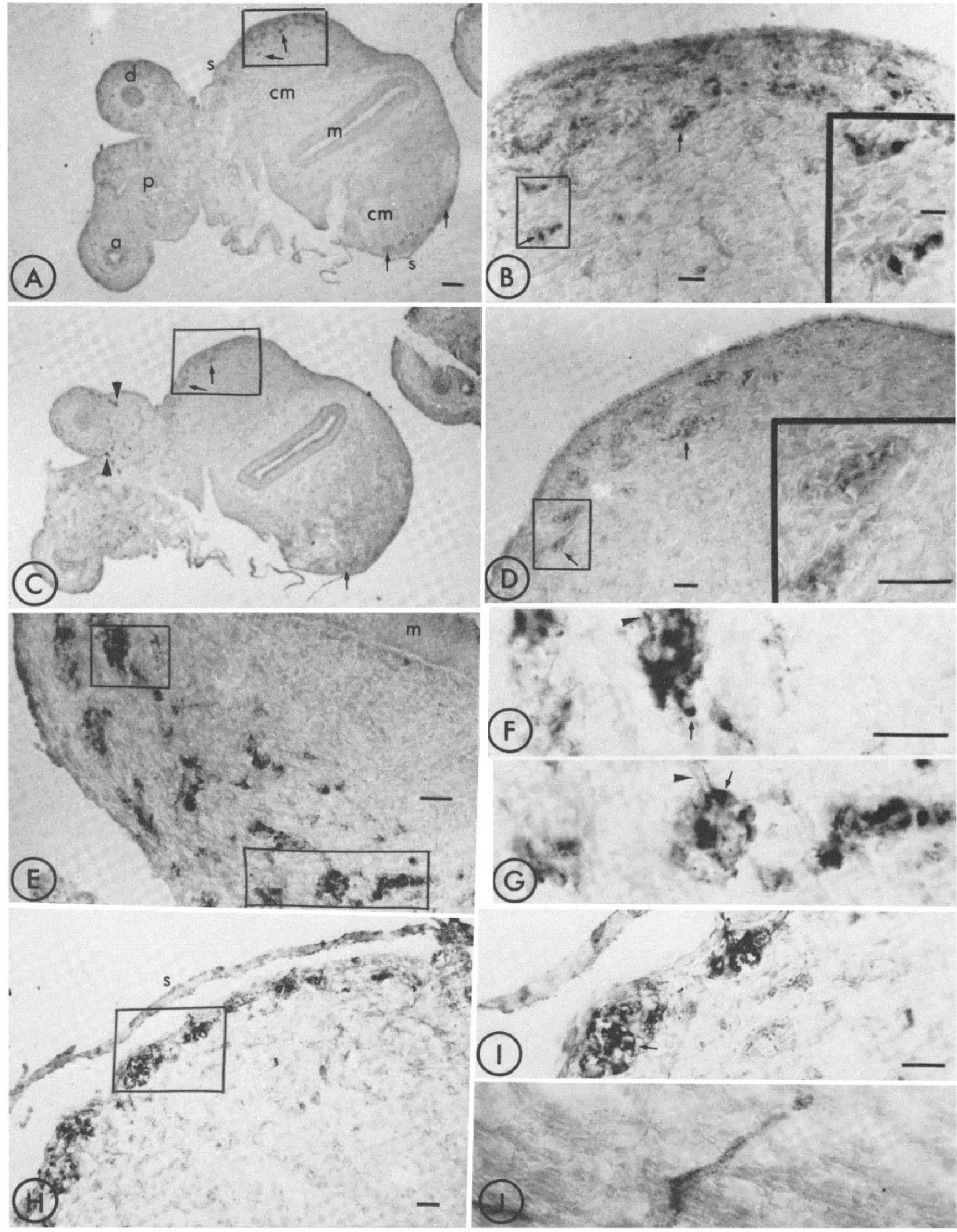

Figure 2, $A-J^{3}$

\footnotetext{
${ }^{3}$ Legends to Figures 2 to 5 are located on p. 2442 .
} 


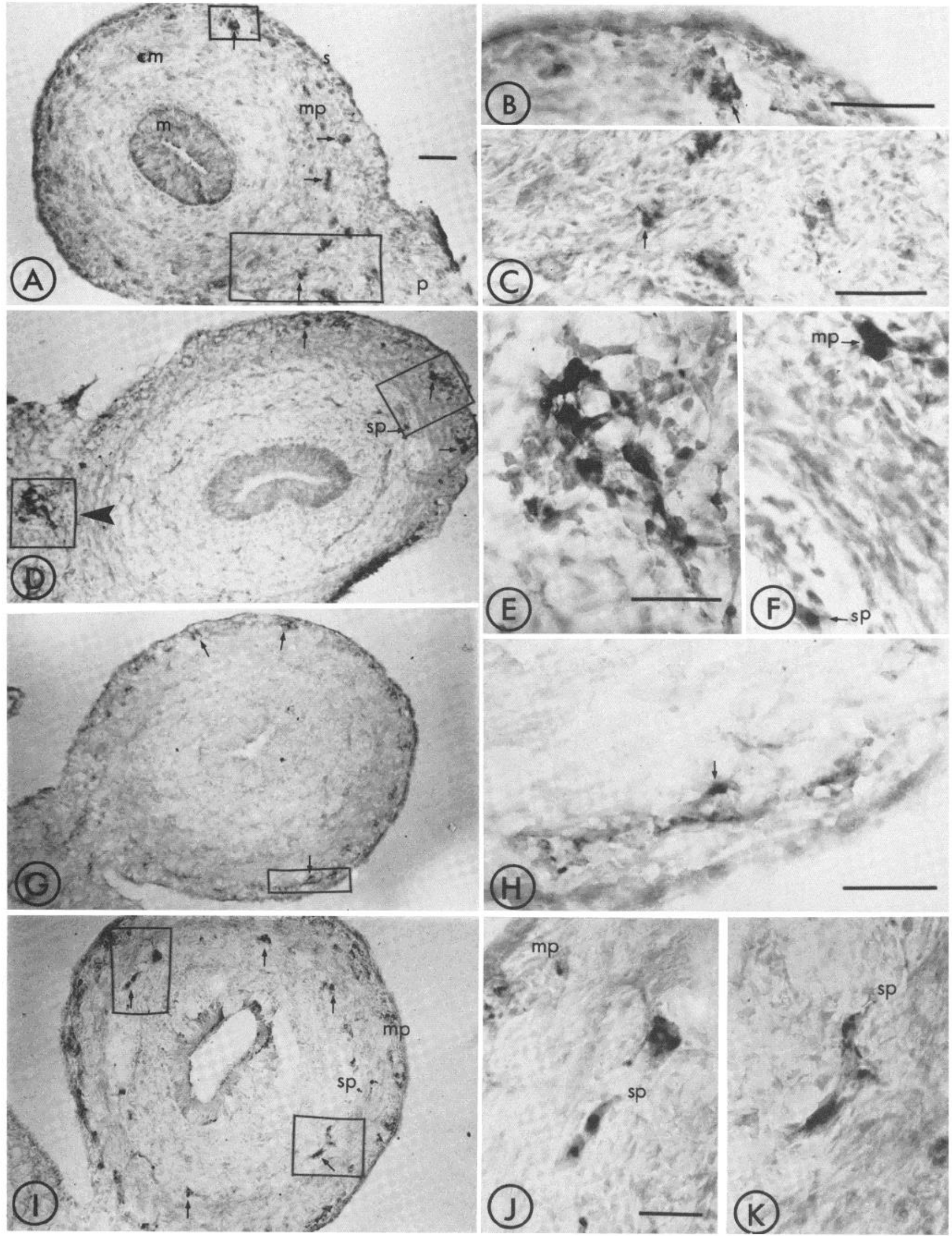

Figure 3, A-K 


\section{ENK}
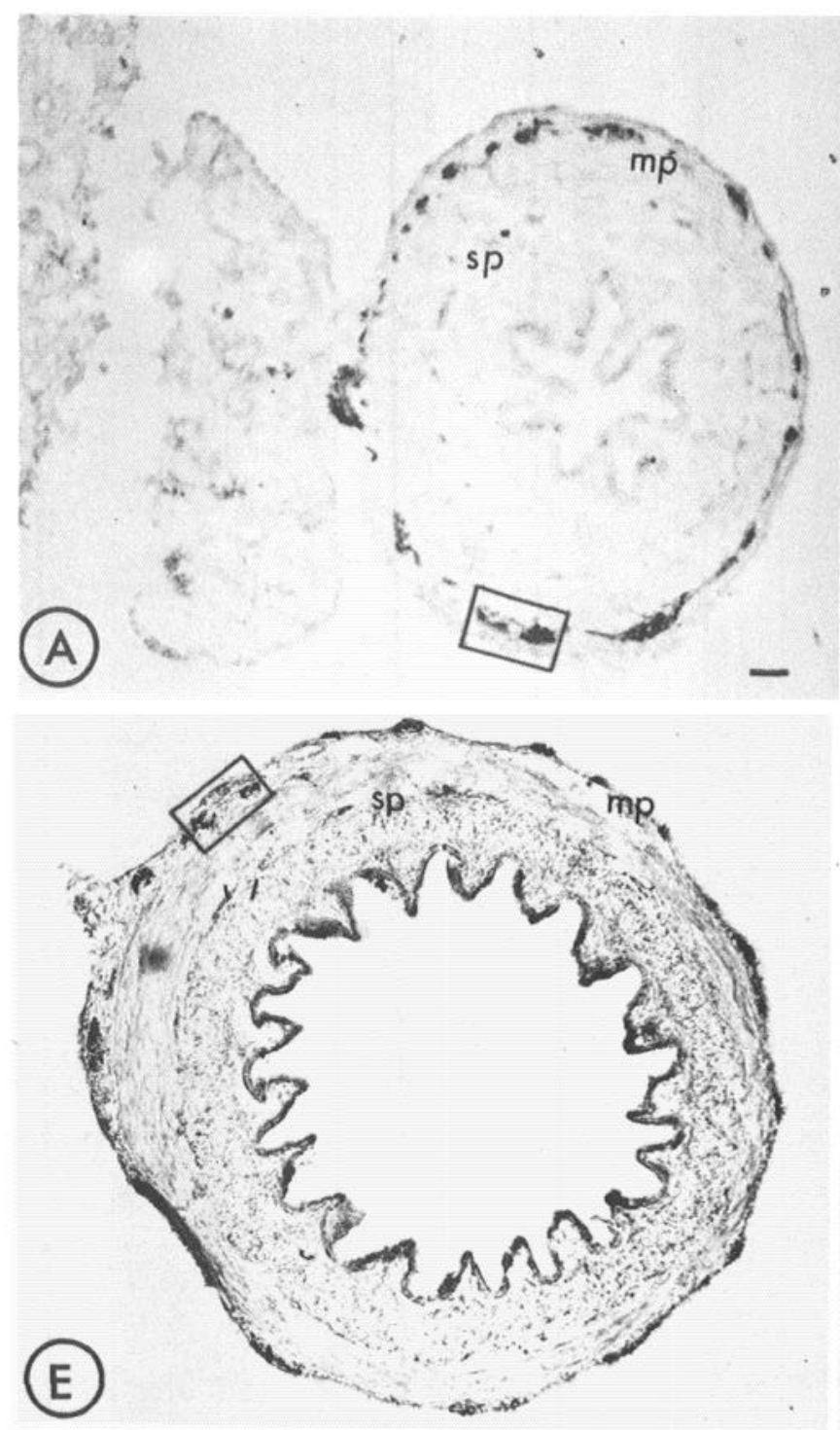

SOM

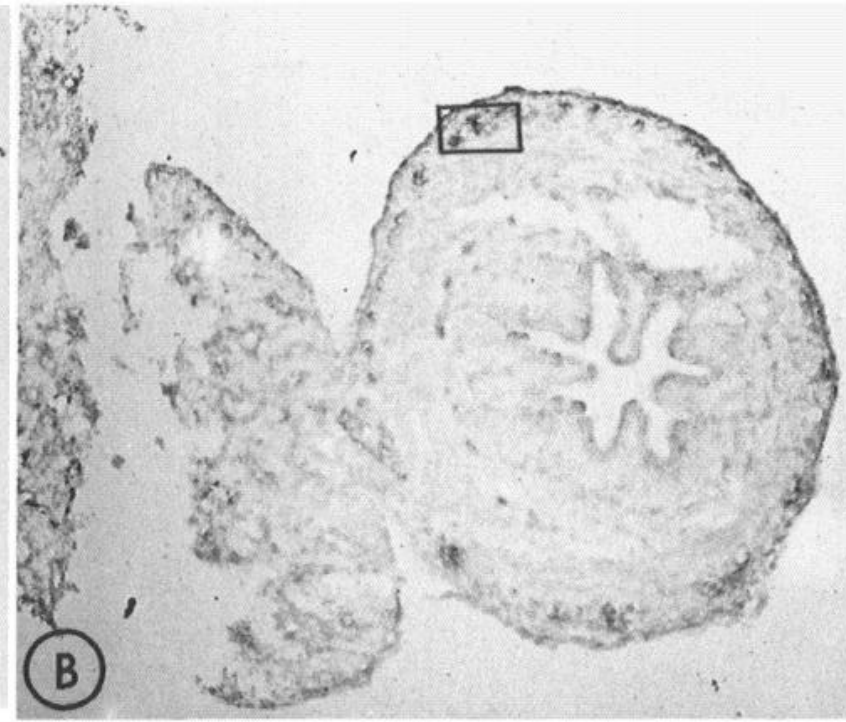

(F)

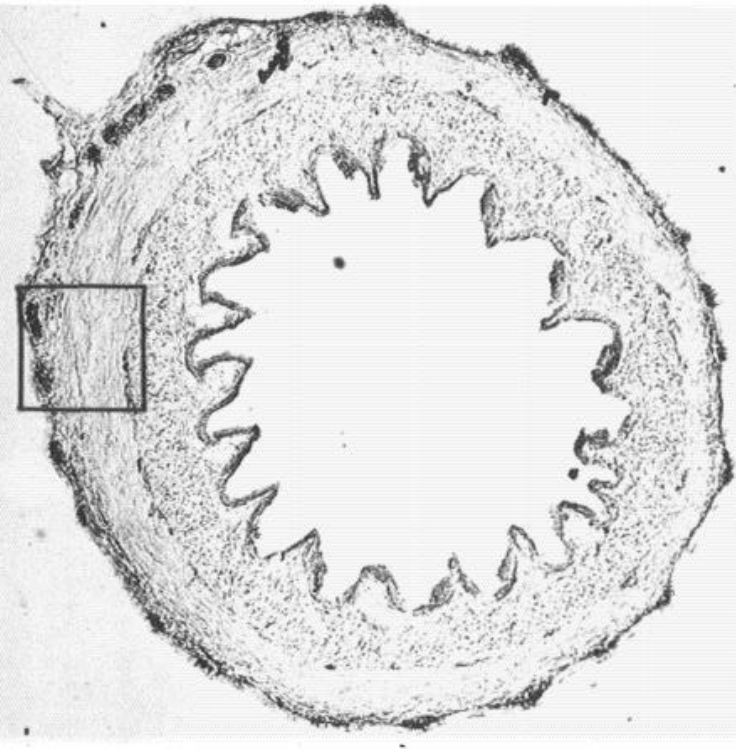

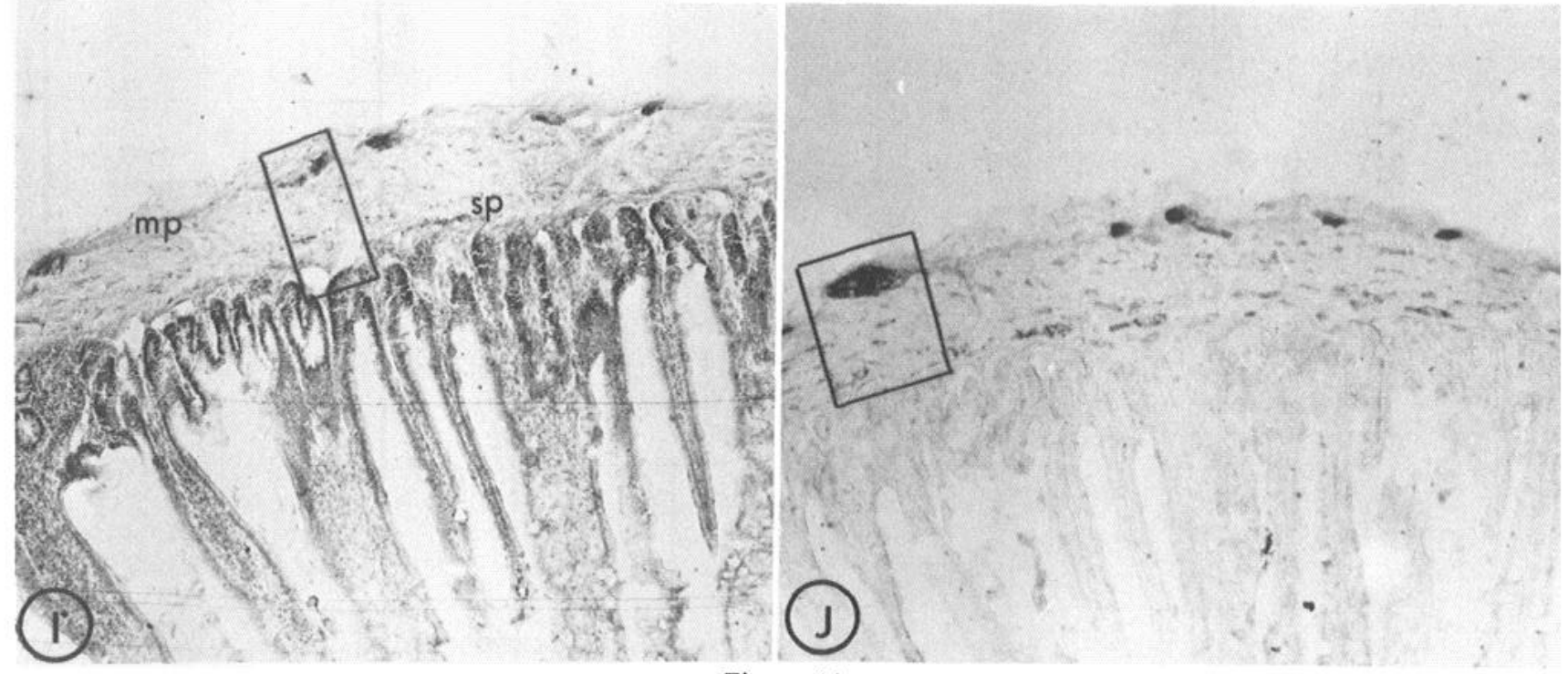


SP

Fy.

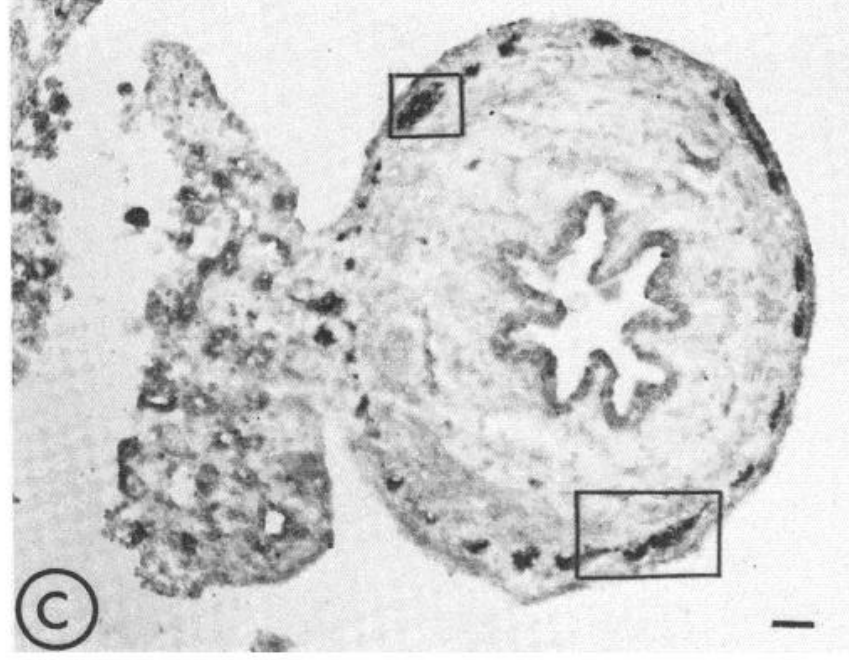

(C)

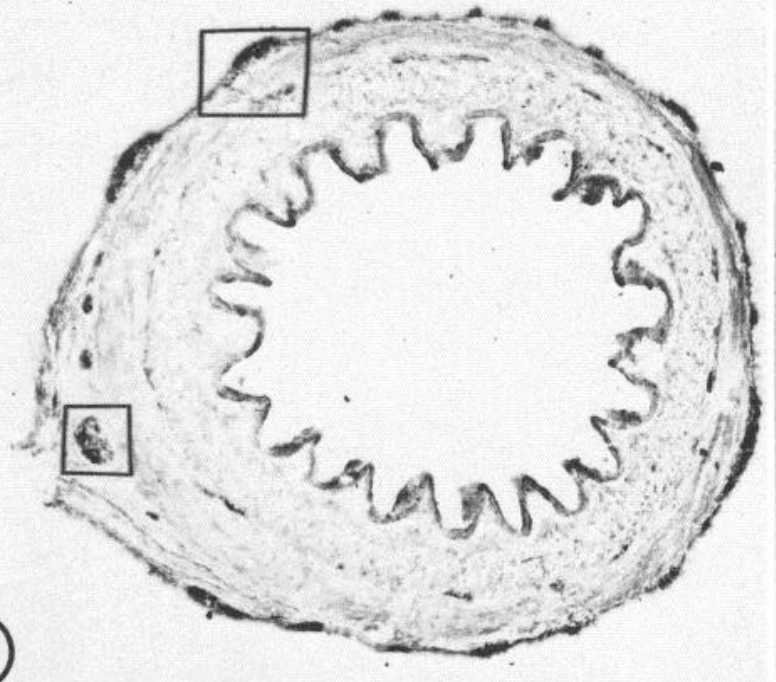

VIP
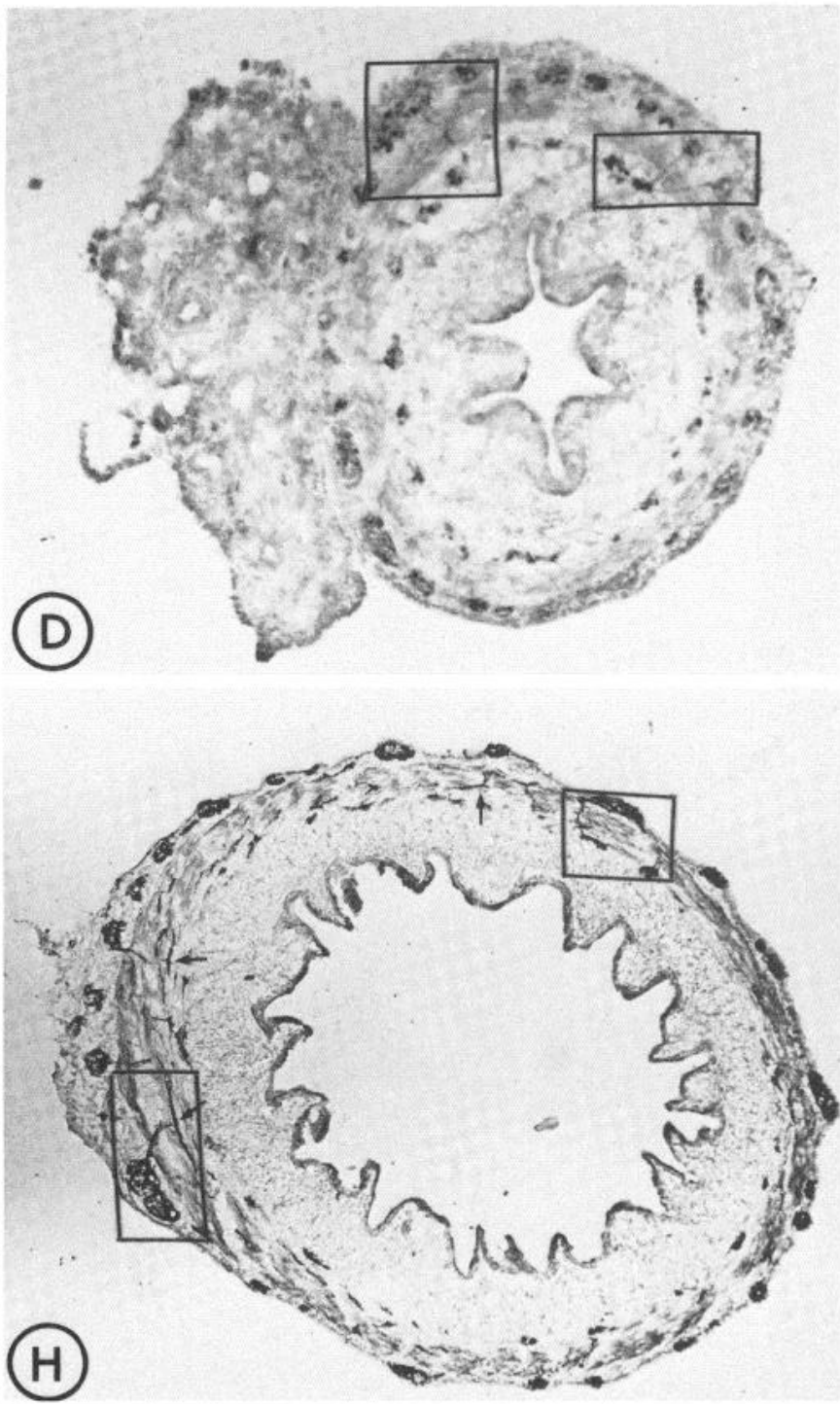
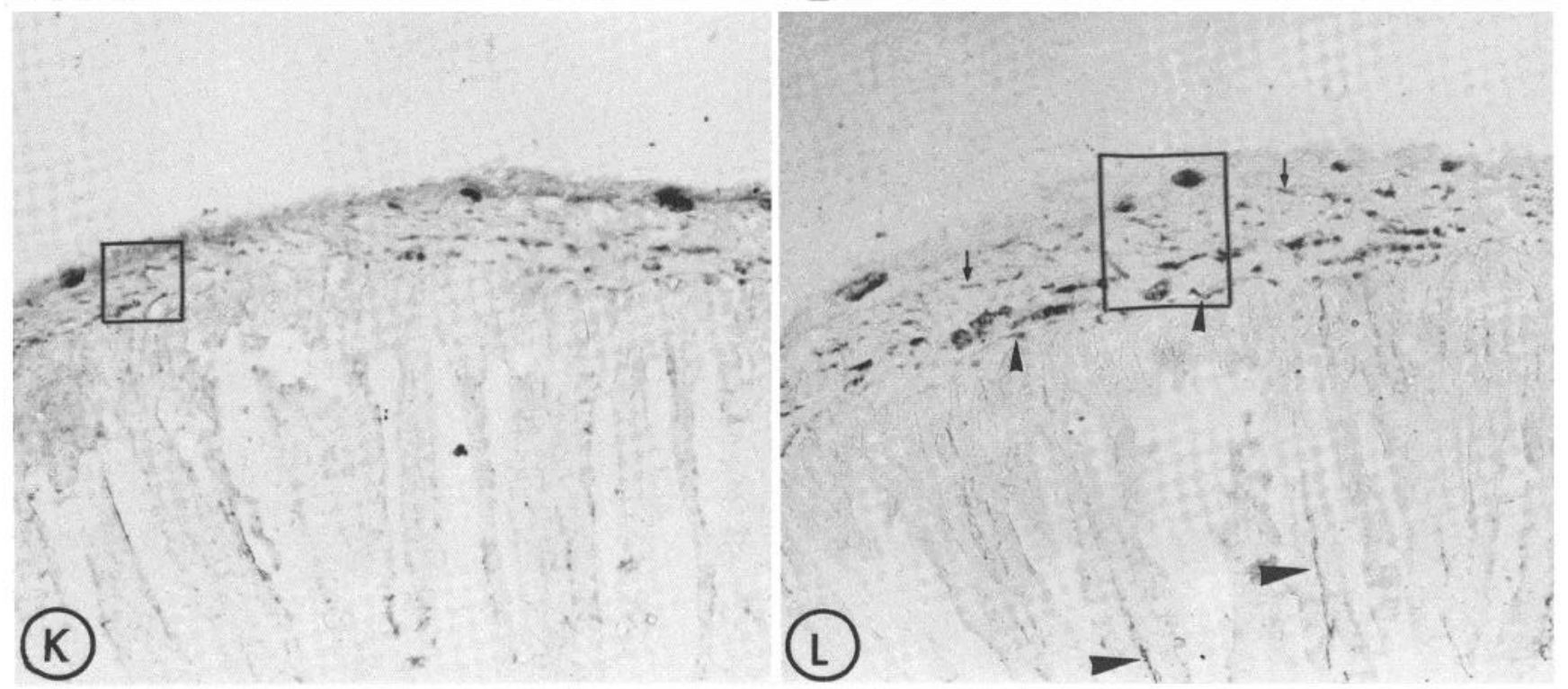


\section{ENK}

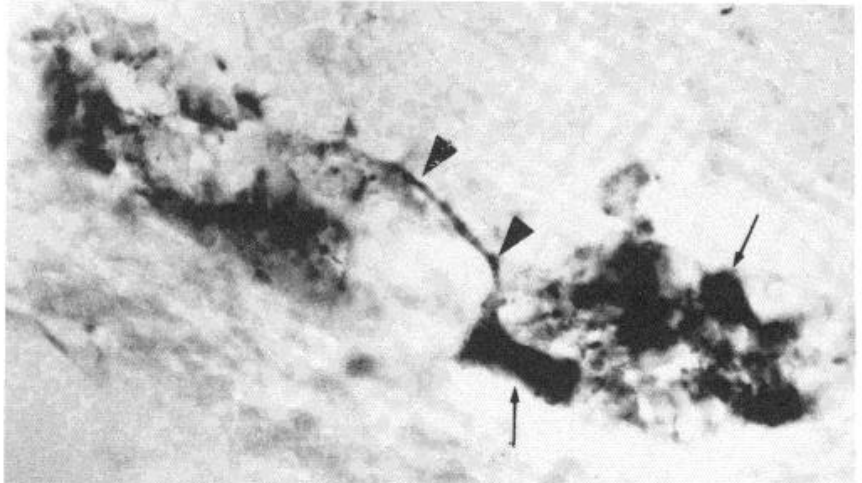

(A)
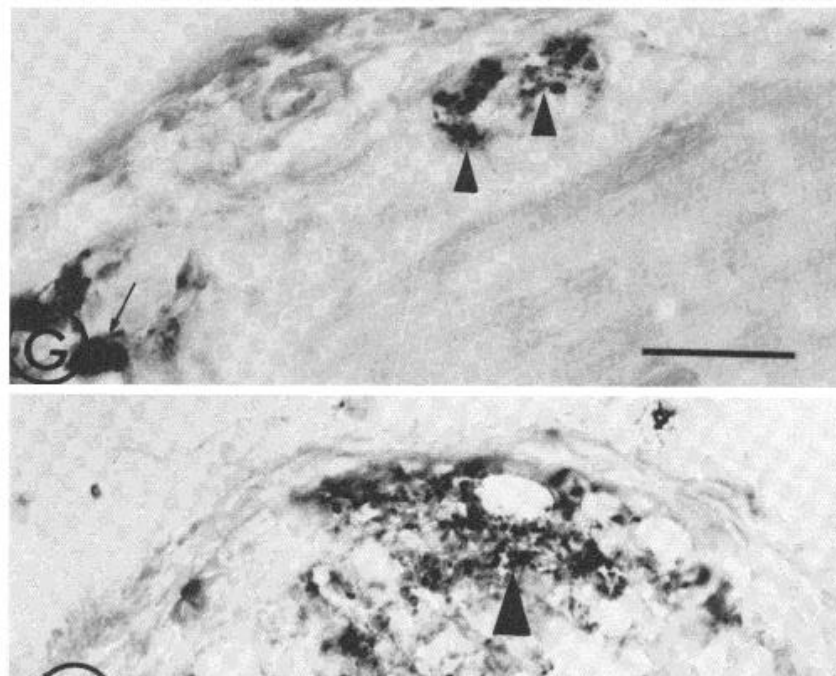

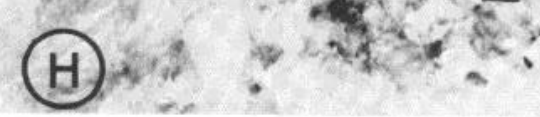

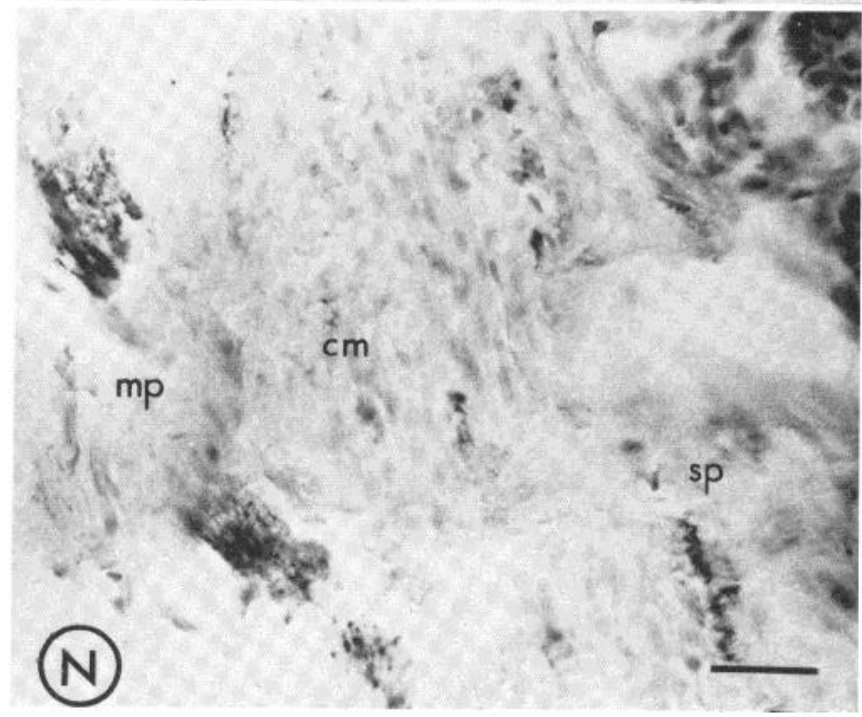

Figure 5A
SOM
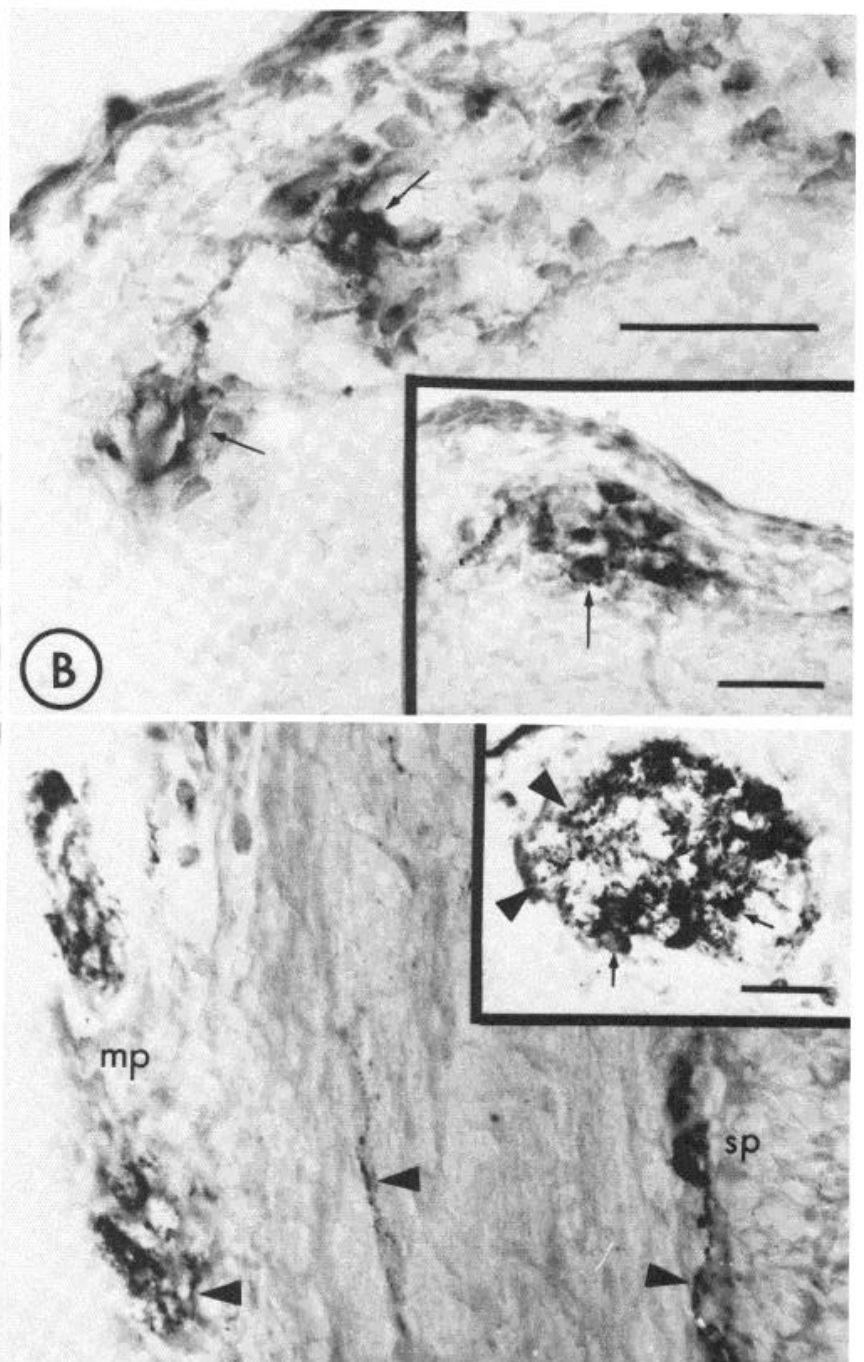

(1)
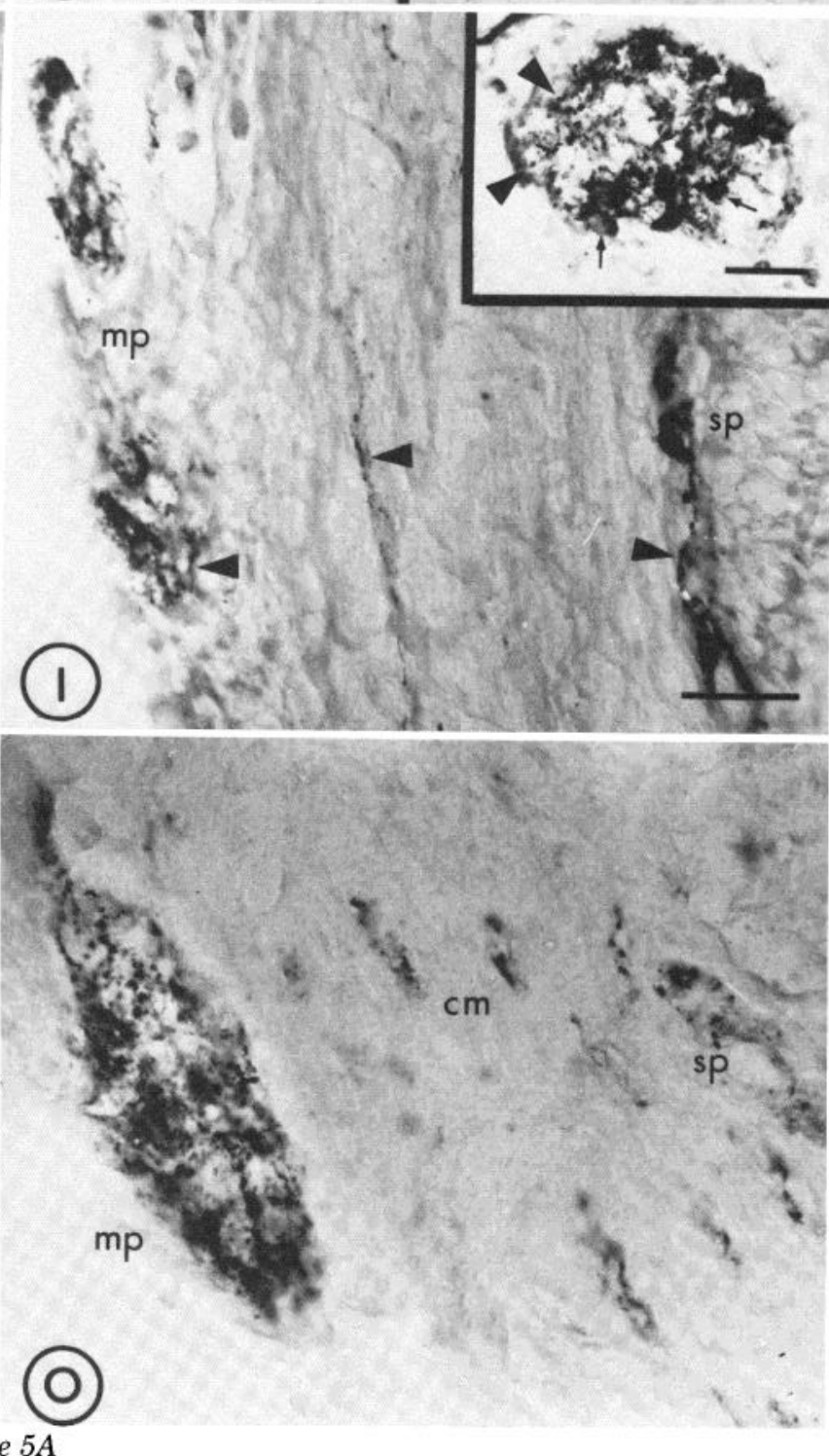


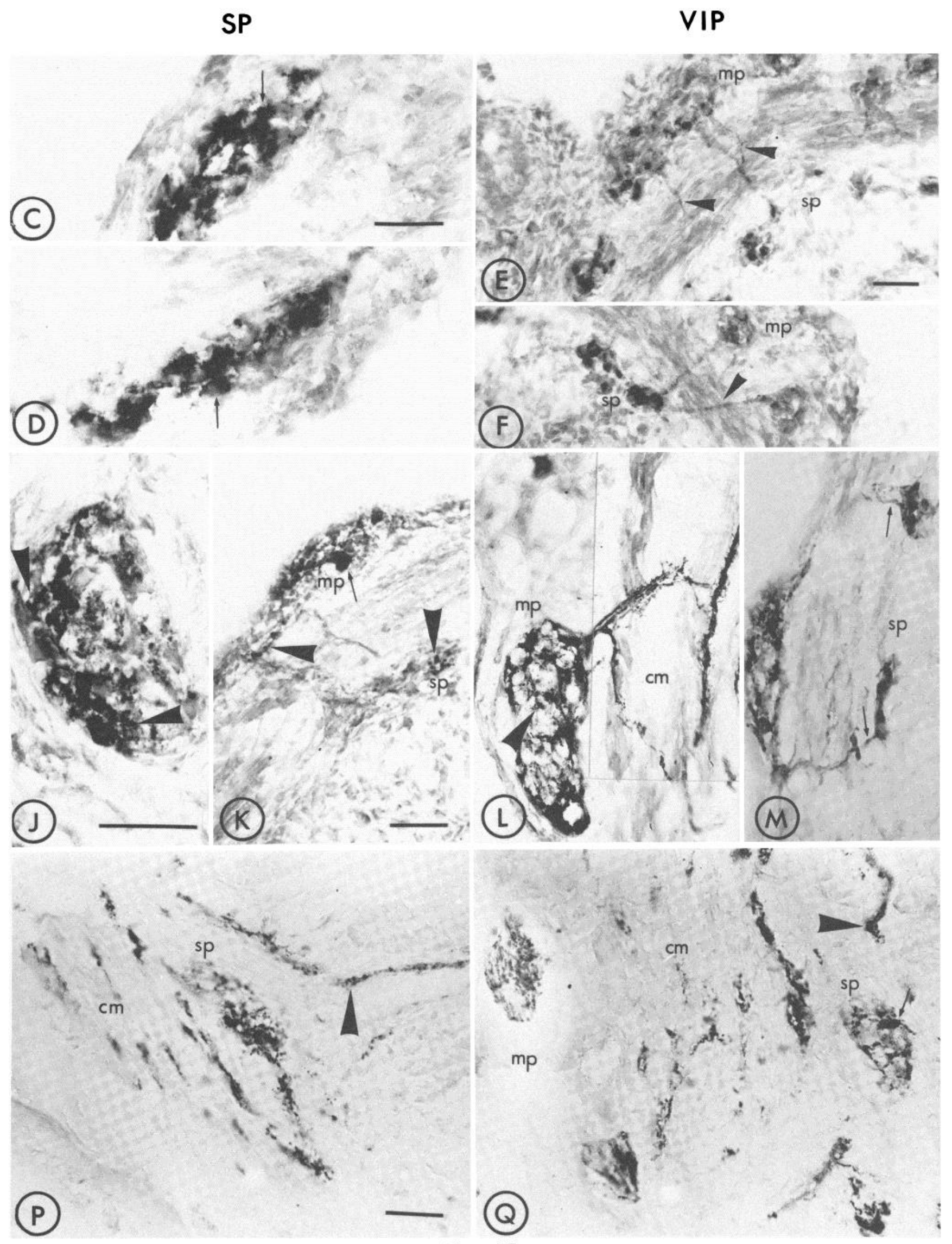

Figure $5 B$ 
Figure 2. Micrographs of transverse sections of 6-day embryonic chick gizzard. A, Clusters of SOM-IR (arrows) are found at the periphery of the layer of developing smooth muscle. Note the characteristically large area of smooth muscle precurosrs ( $\mathrm{cm}$ ) surrounded by serosa $(s)$. In close proximity to the gizzard are the descending $(d)$ and ascending $(a)$ portions of the duodenum which are separated by the developing pancreas $(p)$. $s$, serosa; $m$, mucosa. Scale bar, $100 \mu \mathrm{m}$ in $A$ and $C$. $B$, 'The enclosed section of $A$ at higher magnification. SOM-IR is found in islands of primitive neural elements (arrows). Scale bar, $25 \mu \mathrm{m}$. Inset, The enclosed portion of $B$. SOM-IR is contained within cell bodies located in these islands of neural elements. Scale bar, $10 \mu \mathrm{m}$. $C$, Section from the same region as that shown in $A$. met-ENK-IR (arrows) is found in the same regions of the developing smooth muscle as SOM-IR. Note also the ENK-IR in the duodenum (arrowheads). D, The enclosed portion of $C$ at higher magnification. met-ENK-IR is found in clusters (arrows). Scale bar, $25 \mu \mathrm{m}$. Inset, The enclosed portion of $D$. met-ENK-IR is found in cell bodies. The staining was not as intense as that observed with SOM. Scale bar, $25 \mu \mathrm{m}$. E, Aggregations of VIP-IR are found throughout the area of developing smooth muscle. $m$, mucosa. Scale bar, $25 \mu \mathrm{m}$. $F$ and $G$, The enclosed portions of $E$ at higher magnification. VIP-IR is localized as dense deposits of reaction product within cell bodies (arrows) and in some short processes (arrowheads). Scale bar, $25 \mu \mathrm{m}$ for $F$ and $G$. H, SP-IR is found in islands in the putative myenteric plexus at the junction of the developing smooth muscle and serosa $(s)$. The serosa has separated from the smooth muscle. Scale bar, $25 \mu \mathrm{m}$. $I$, The enclosed portion of $H$ at higher magnification. SP-IR is found within cell bodies (arrow). Scale bar, $25 \mu \mathrm{m}$ for $I$ and $J$. $J$, A SP-IR fiber in the middle of the developing smooth muscle.

Figure 3. Micrographs of transverse sections of duodenum from 6 to 7 d.i. embryonic chick showing peptide immunoreactivity. $A$, met-ENK-IR (arrows) in 6-day embryonic duodenum is found around a part of the circumference of the duodenum in the region of the putative myenteric plexus $(m p)$ and at the junction of the pancreas $(p)$ and duodenum. $\mathrm{cm}$, circular smooth muscle; $s$, serosa; $m$, mucosa. Scale bar, $50 \mu \mathrm{m}$ for $A, D, G$, and $I . B$ and $C$, The enclosed portions of $A$ at higher magnification. metENK-IR is found within cell bodies (arrows). Scale bar, $50 \mu \mathrm{m}$ for $B$ and $C$. D, SOM-IR in 7-day embryonic duodenum is found in a small number of cells (arrows) located in the region of the putative myenteric plexus. A large cluster of cells (arrowhead) is seen at the junction of the pancreas and duodenum. A cell containing SOM-IR is seen in the submucosal plexus ( $s p$ ). $E$, The enclosed portion of $D$ at higher magnification. SOM-IR is localized within cell bodies at the junction of the duodenum and pancreas. Scale bar, $25 \mu \mathrm{m}$ for $E$ and $F$. $F$, The enclosed portion of $D$ at higher magnification. SOM-IR cells are found in the myenteric plexus $(m p)$ and submucosal plexus $(s p)$. $G$, Small amounts of SP-IR (arrows) are found around the circumference of the 7-day embryonic duodenum. $H$, The enclosed portion of $G$ at higher magnification. Small amounts of SP-IR are visible. One cell body (arrow) can be seen. Scale bar, $25 \mu \mathrm{m}$. I, VIP-IR in 7-day embryonic duodenum. VIP-IR is visualized in the region of the putative myenteric plexus $(m p)$ and in the submucosal plexus $(s p)$ (arrows). $J$ and $K$, The enclosed portions of $I$ at higher magnification. VIP-IR is shown within cell bodies in the submucosal plexus. Immunoreactivity, probably in cell bodies, is also seen in the myenteric plexus ( $m p$ in $J$ ). Note that the cell bodies are more distinctly localized than was seen with SP antisera. Scale bar, $25 \mu \mathrm{m}$ for $J$ and $K$.

Figure 4. A to $D$, Micrographs of transverse sections of 9-day embryonic chick duodenum showing $(A)$ met-ENK-IR, $(B)$ SOM-IR $(C)$ SP-IR, and $(D)$ VIP-IR around the circumference in the region of the putative myenteric plexus $(m p)$. Intense VIP-IR is seen in the submucosal plexus $(D) . A$ to $C$ are adjacent sections. $D$ is from another preparation. $S c a l e b a r, 50 \mu \mathrm{m}$ for all micrographs; all micrographs are at the same magnification. $E$ to $H$, Micrographs of transverse sections of 13 -day embryonic chick duodenum showing $(E)$ met-ENK-IR, $(F)$ SOM-IR, $(G)$ SP-IR, and $(H)$ VIP-IR present in large discrete clusters in the myenteric plexus $(m p)$. Smaller amounts of immunoreactivity are found in the submucosal plexus $(s p)$. An extensive array of VIP-IR fibers is found in the circular smooth muscle (arrows) $(H)$. $I$ to $L$, Micrographs of transverse sections of duodenum from newly hatched chick showing $(I)$ met-ENK-IR, $(J)$ SOM-IR $(K)$ SP-IR, and $(L)$ VIP-IR in widely separated areas in the myenteric plexus $(m p)$. Considerable VIP-IR is found in the submucosal plexus $(L)$. VIP-IR is also found in fibers in the circular smooth muscle (arrows), the mucosal plexus (small arrowheads), and the villi (large arrowheads). The section shown in $I$ was counterstained with cresyl violet.

Figure 5. $A$ to $F$, Micrographs of transverse sections of 9-day embryonic chick duodenum showing $(A)$ met-ENK-IR, $(B)$ SOM-IR, $(C$ and $D$ ) SP-IR and $(E$ and $F$ ) VIP-IR. $A$, The enclosed portion of Figure $4 A$ at higher magnification. met-ENK-IR is localized to cell bodies (arrows). One cell body shows a short process containing varicosities (arrowheads). Scale bar, $25 \mu \mathrm{m}$ for all micrographs. $B$, The enclosed portion of Figure $4 B$ at higher magnification. SOM-IR is found in the myenteric plexus (arrows). Inset, Micrograph from another section showing cell bodies (arrows) with SOM-IR. $C$ and $D$, Portions of Figure $4 C$ at higher magnification. SP-IR is localized to cell bodies (arrows). Scale bar, $25 \mu \mathrm{m}$ for $C$ and $D$. $E$ and $F$, The enclosed portions of Figure $4 D$ at higher magnification. VIP-IR cell bodies are found in both the submucosal $(s p)$ and the myenteric plexus ( $m p$ ), which appear to be connected by immunoreactive processes (arrowheads). Scale bar, $25 \mu \mathrm{m}$ for $E$ and $F$. $G$ to $M$, Micrographs of transverse sections of 13-day embryonic chick duodenum at high magnification showing $(G$ and $H)$ met-ENK-IR, $(I)$ SOM-IR, $(J$ and $K)$ SP-IR, and ( $L$ and $M$ ) VIP-IR. $G$, The enclosed portion of Figure $4 E$ at higher magnification. met-ENK-IR is found in varicosities (arrowheads) and cell bodies (arrow). Scale bar, $25 \mu \mathrm{m}$ for $G$ and $H$. H, A portion of another section showing ENK-IR in varicosities (arrowhead) in the myenteric plexus. I, The enclosed portion of Figure $4 F$ at higher magnification showing SOM-IR in varicosities in the myenteric plexus $(\mathrm{mp})$, the submucosal plexus $(s p)$, and the circular smooth muscle (arrowheads). Inset, Another section showing SOM-IR cell bodies (arrows) and varicosities (arrowheads) in the myenteric plexus. $J$, The enclosed portion of Figure $4 G$ showing SP-IR varicosities (arrowheads) in the myenteric plexus. $K$, The enclosed portion of Figure $4 G$ showing SP-IR in a cell body (arrow) and varicosities (arrowheads) in the myenteric plexus (mp) and in the submucosal plexus $(s p)$. Scale bar, $25 \mu \mathrm{m}$ for $K, L$, and $M$. $L$, A montage of the enclosed portion of Figure $4 H$ showing VIP-IR processes and varicosities (arrowhead) in the myenteric plexus $(m p)$. VIP-IR fibers appear to originate from the plexus and branch in the circular smooth muscle $(\mathrm{cm})$. $M$. The enclused portion of Figure $4 H$ at higher magnification showing VIP-IR cell bodies in the submucosal plexus $(s p)$ which extend processes (arrows) into the circular smooth muscle. $N$ to $Q$, Micrographs of transverse sections of duodenum from newly hatched chick showing $(N)$ met-ENK-IR, $(O)$ SOM-IR, $(P)$ SP-IR, and $(Q)$ VIPIR. $N$, The enclosed portion of Figure $4 I$ at higher magnification. met-ENK-IR varicosities are found in the myenteric plexus $(\mathrm{mp})$, the submucosal plexus $(\mathrm{sp})$, and circular smooth muscle $(\mathrm{cm})$. Scale bar, $25 \mu \mathrm{m}$ for $N$ and $O$. $O$, The enclosed portion of Figure $4 J$ at higher magnification. SOM-IR varicosities are found in the myenteric plexus ( $m p)$, the submucosal plexus ( $s p)$, and the circular smooth muscle $(\mathrm{cm})$. $P$, The enclosed portion of Figure $4 K$ at higher magnification showing SP-IR varicosities in the submucosal plexus $(s p)$, the circular smooth muscle $(\mathrm{cm}$ ), and the mucosal plexus (arrowhead) in the lamina propria at the base of the mucosal epithelium. Scale bar, $25 \mu \mathrm{m}$ for $P$ and $Q$. $Q$, The enclosed portion of Figure $4 L$ at higher magnification showing VIP-IR varicosities in the myenteric plexus $(m p)$, the submucosal plexus $(s p)$, the circular smooth muscle $(\mathrm{cm})$, and mucosal plexus (arrowhead). A cell body is also visible in the submucosal plexus (arrow). 

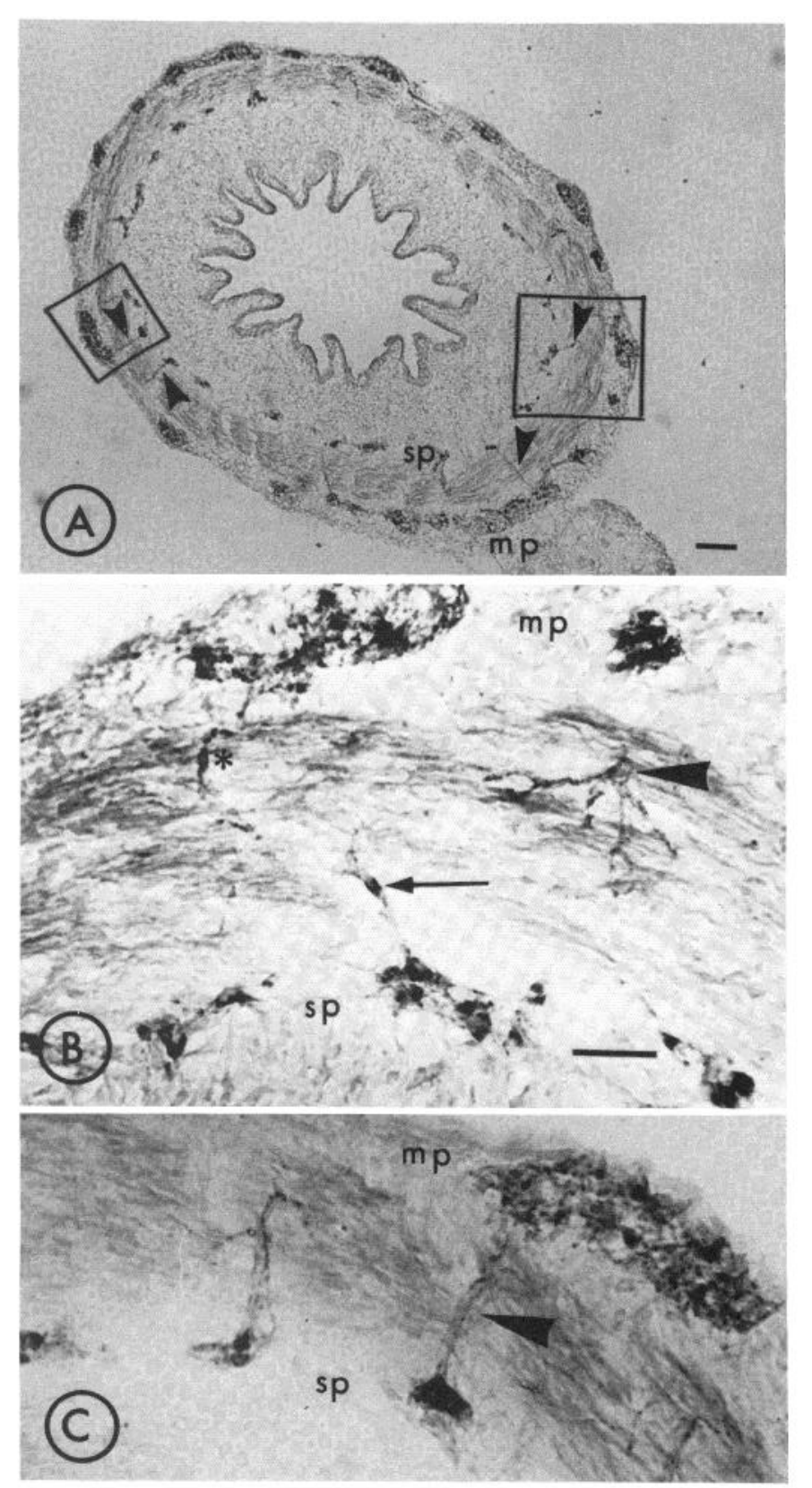

Figure 6. Micrographs of transverse sections of duodenum from 11-day embryonic chick. $A$, VIP-IR is found in both the myenteric $(m p)$ and submucosal $(s p)$ plexuses. A number of immunoreactive fibers appear to originate from the submucosal plexus (arrowheads). Scale bar, $50 \mu \mathrm{m}$. B, The enclosed portion on the left side of $A$ at higher magnification. A cell containing VIP-IR is seen in the middle of the circular smooth muscle (arrow). Another immunoreactive cell is located on the peripheral border of the circular smooth muscle (asterisk). Immunoreactive fibers are found in the circular smooth muscle (arrowhead). Note the absence of varicosities in the submucosal plexus $(s p)$ in contrast to their presence in the myenteric plexus $(\mathrm{mp})$. Scale bar, $25 \mu \mathrm{m}$ for $B$ and $C$. $C$, The enclosed portion on the right side of $A$ at higher magnification. VIP-IR processes ( $a r$ rowhead) appear to leave the submucosal plexus ( $s p)$ and extend toward the myenteric plexus $(\mathrm{mp})$. were found in the submucosal plexus and in fibers in the circular smooth muscle and the least in the mucosal plexus. met-ENK-IR and SOM-IR appeared in roughly equal amounts, with the area of heaviest concentration being the myenteric plexus; there were much smaller amounts in the submucosal plexus and in occasional fibers in the smooth muscle.

We have carried out experiments to determine if the peptide-containing cells in very early embryonic gut could be identified as neurons. The 210 -kilodalton neurofilament protein was used as a neuronal marker; the presence of this protein was revealed by staining with a monoclonal antibody (Anderton et al., 1982). As shown in Figure 7, peptide and neurofilament protein immunoreactivities appear to occupy coincidental positions in some cells (Fig. 7, arrows) and processes (Fig. 7, arrowheads). Not all peptide-containing cell bodies are coincidentally stained for neurofilament protein, however. At later stages of development, most peptide-containing processes possess neurofilament protein immunoreactivities.

\section{Discussion}

We have used immunocytochemistry to describe the development of four peptidergic neuronal systems in the foregut of the chick. As indicated in Table II, metENK-, SOM-, SP-, and VIP-IR were all detected very early in ontogeny, in the 4- to 9-day embryonic foregut. Others who have studied the development of peptides in chick gut have not found evidence for their presence until later. For example, Sundler et al. (1979) first found VIP-IR in the proventriculus at 13 d.i., whereas Fontaine-Perus et al. (1981) detected VIP- and SP-IR in the chick foregut at 10 d.i. We have no explanation for their failure to detect peptides at earlier ages. It is possible that our antisera have greater sensitivities, thus permitting the detection of the low levels of immunoreactivity present at very early stages of embryonic development. Our ability to detect these peptides is not dependent on the use of different fixatives, as we have found these peptides at early stages in both formaldehyde- and benzoquinone-treated material.

From our results using double staining for peptides and neurofilament protein, we conclude that some of the peptide-containing cells present at very early stages of development are neurons. Because of the $10-$ to $12-\mu \mathrm{m}$ thickness of the sections, we cannot rule out the possibility that these immunoreactivities are in different structures. However, the congruence of the profiles of immunoreactivity suggests they are in the same structures. In older embryos, peptide and neurofilament immunoreactivities were coincident in cell processes in most cases. The failure to find neurofilament protein in all of the peptide-containing cells present at very early stages of development may reflect differences in the sequence of gene expression and/or differences in the localization of the peptides and neurofilament protein within the developing cells. Experiments are in progress to examine these possibilities.

It seems unlikely that the peptide-containing cells in the early embryo are migrating enteroendocrine cells. Although we cannot completely exclude this possibility, 

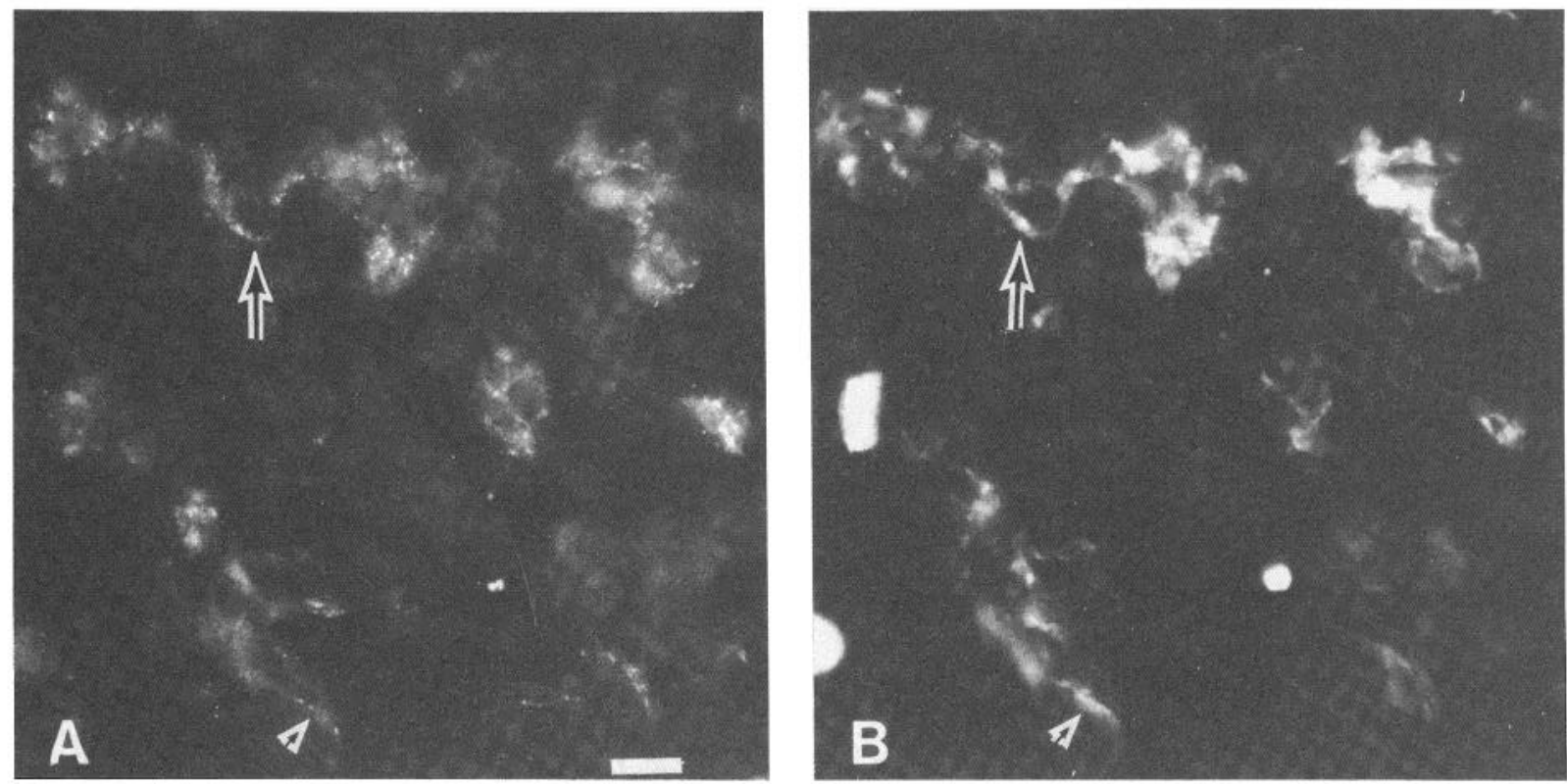

Figure 7. Micrographs of a section of gizzard taken from 7-day embryonic chick. The same section showing the presence of FITC fluroescence $(A)$, indicating the presence of leu-ENK immunoreactivity, and TRITC fluorescence $(B)$, indicating the presence of neurofilament protein immunoreactivity. The coincidence of staining for leu-ENK and neurofilament protein in a cell (arrow) and cell process (arrowhead) is indicated. Scale bar, $10 \mu \mathrm{m}$.

the following evidence strongly argues against it. (1) The peptide-containing cells are found in the gut area (putative myenteric plexus) which contains developing neurons, as indicated by the presence of neurofilament protein immunoreactivity. (2) In preliminary observations (D. M. Noden and M. L. Epstein, unpublished observations) of quail neural tube transplanted into chick hosts, quail neural crest cells were found to constitute all of the myenteric plexus in sections of the gizzard and duodenum; peptide-containing cells were found in the myenteric plexus of these gut regions. Since enteroendocrine cells do not arise from the neural crest (LeDouarin and Teillet, 1973) and enteric neurons do, these results suggest that the peptide-containing cells are neurons and not enteroendocrine cells.

There is evidence that other neurons declare their phenotypes very early in the development of the chick gut. Choline acetyltransferase is present in the duodenum at 6 to 7 d.i. (Smith et al., 1977); selective uptake of serotonin appears somewhat later, at 7 to 8 d.i. (Epstein et al., 1980; Gershon et al., 1980). Our results indicate that, at least in the chicken duodenum, both acetylcholine and putative peptide neurotransmitters appear at about the same time in ontogeny. This argues against the sequential developmental pattern proposed by Saffrey et al. (1982), in which peptidergic neurons appear later than those containing enzymes catalyzing acetylcholine production or serotonin uptake. In this regard, it is interesting that putative peptide neurotransmitters may coexist in the same neuron with small molecule neurotransmitters (Hokfelt et al., 1980) as well as with other peptides (Hokfelt et al., 1980; Erichsen et al., 1982). Although the different peptide immunoreactivities described here may coexist within the same cell, we have not looked for such a possibility.
The results summarized in Table II show differences in the times at which the various peptides were first detected in different regions of the gut. For example, met-ENK-IR was found at $5 \mathrm{~d}$.i. in the gizzard and duodenum, but not until 9 d.i. in the proventriculus. SOM-IR was first observed at 4 d.i. in the gizzard, at 7 d.i. in the duodenum, and not until 11 d.i. in the proventriculus, and then in only a few fibers in the myenteric plexus. In contrast, VIP and SP were detected at essentially the same times, 5 and 6 to 7 d.i., respectively, in all regions of the gut examined. Differences in the order of appearance of the four peptides in different gut regions were also observed. For example, SOM-IR was the first to be detected in the gizzard and the last to be detected in the duodenum. Thus, our data show no common pattern in the time or order of appearance of these peptides in different regions of the foregut. The significance of these observations is not known.

Establishing the time of appearance of the different peptides depends on the ability to detect small amounts of immunoreactivity. It is not clear whether our results accurately reflect the sequence of appearance in the tissues studied or instead reflect differences in the sensitivity of the antisera used. Immunocytochemical detection of antigen depends on a number of factors including the amount of antigen within the cell and the affinity of the antibody for the antigen. Enough antigen must be present to give an amount of staining which is distinguishable from the background and which may be different for each antiserum. The affinity of the antigen is probably less critical as an excess of antiserum is used. Moreover, antisera which are highly specific as determined by radioimmunoassay do not necessarily produce optimal immunocytochemical staining (Fig. 2 in Swaab, et al., 1975). 
Our results clearly indicate the presence of peptide immunoreactivity at early stages of development. However, verification of the sequence of appearance must await use of specific radioimmunoassays in conjunction with high pressure liquid chromatography to characterize the immunoreactivity being measured. In previous studies, we found that met-ENK-IR in the duodenum was detected at essentially the same time by radioimmunoassay (5 d.i.) (Epstein et al., 1981) as by immunocytochemistry ( 5 d.i. in this study). In addition, the fact that we can detect SOM at 4 d.i. in the gizzard but not until 7 to 9 d.i. in the duodenum argues against the possibility that the appearance of the peptides reflects a difference in the sensitivity of our antisera. Thus, the results reported here probably reflect the correct sequence, but not necessarily the precise time of appearance in the tissues.

Although the peptide-containing cells observed in our work are found in the myenteric plexus throughout ontogeny and after hatching, we cannot rule out the possibility that the peptide-containing cells are transient in their appearance. Transient catecholamine-producing cells have been described in the developing rat (Cochard et al., 1978; Teitelman et al., 1978) and mouse gut (Teitelman et al., 1981). We do not know whether the presence of peptide immunoreactivity represents a commitment of a cell to a peptide phenotype or merely a brief episode in the sequence of development. As others have observed (Patterson, 1978; Potter et al., 1983), individual cultured sympathetic neurons show an adrenergic phenotype under one set of culture conditions and can express a cholinergic phenotype under a different set of conditions. Hence the production of catecholamines need not represent an irrevocable commitment to that phenotype.

Although all four peptides were obscrved in cell bodies in the gizzard and duodenum of the chick, SOM-IR cell bodies were rarely observed in the wall of the proventriculus. Schultzberg et al. (1980) similarly reported that, although there were a moderate number of SOM-IR cell bodies in the small intestine of the guinea pig and a small number in the rat intestine, there were none in the stomach of the rat or in the fundus of the stomach of the guinea pig. They also found cell bodies containing dopamine $\beta$-hydroxylase (a marker for norepinephrine neurons) and gastrin/cholecystokinin immunoreactivity only in certain gut regions. Saffrey et al. (1982) found neurotensin cell bodies restricted to the gizzard and proventriculus. The physiological significance of these regional differences is not understood.

What these results do indicate is that expression of certain neurotransmitter phenotypes is limited in certain gut regions. It has been demonstrated that vagal neural crest cells migrate along the length of the gut and are found in the foregut at 3 to $4 \mathrm{~d}$.i. (LeDouarin and Teillet, 1973 ) and the jejunum at about $4 \frac{1}{2}$ d.i. (Allan and Newgreen, 1980). The phenotypic expression of these neuronal precursors has been shown to be influenced by the microcnvironment in general (Patterson, 1978) and by that of the gut in particular (LeDouarin, 1980). The microenvironment may vary along the length of the gut and may permit the expression of only certain peptide phenotypes in certain regions. The sparsity of SOM-IR cell bodies during development of the proventriculus and their very early appearance in the gizzard are consistent with the concept that each type of peptidergic neuron may express its phenotype independently in an appropriate or permissive environment. Our data argue against a predetermined sequence which is the same in all gut regions.

We have compared the changes in the localization of immunoreactivity in the four types of peptidergic neurons in the duodenum (Table II). Certain similarities are apparent. All four peptides were first localized to cell bodies in the myenteric plexus and first appeared at 5 to 7 d.i. The number of immunoreactive cell bodies increased dramatically from 5 to 9 d.i. At this time, short immunoreactive processes were found on some cell bodies, particularly the VIP-IR cells. At 11 to 13 d.i., more processes were visualized. Isolated varicosities and varicosities associated with immunoreactive processes were also apparent in the myenteric and submucosal plexuses. From 13 d.i. until the time of hatching, the varicosities increased in number and staining intensity; at hatching, the myenteric and submucosal plexuses contained a large number of immunoreactive varicosities but fewer immunoreactive cell bodies than were found at earlier times in development.

A number of differences in the differentiation of these peptidergic neurons were also observed. Immunoreactive cell bodies appeared at different times in the submucosal plexus. The first to be detected was VIP, which was found in many of the cells in the submucosal plexus at 5 to 9 d.i. At later times, a small number of immunoreactive cells containing SOM and SP were also seen in the submucosal plexus. No immunoreactive met-ENK cells were ever seen in the submucosal plexus. The VIP-IR cells showed processes which extended across the smooth muscle toward the myenteric plexus. These were first seen at 9 d.i., were prominent at 11 d.i. (Fig. 6), but were no longer apparent at 13 d.i. On the basis of results obtained with separate cultures of myenteric and submucosal neurons from the guinea pig cecum, Jessen et al. (1980) concluded that VIP submucosal neurons project to the myenteric plexus. Our observations, seen in an in vivo preparation, support this idea; our inability to visualize these connections later in development does not mean they are absent. More likely, with increased growth of the gut, the submucosal plexus neurons and their putative connections in the myenteric plexus would not be in the same 10- to $20-\mu \mathrm{m}$ section. However, when the gut is small and compact during development, they can be visualized.

The data summarized in Table II show that the circular smooth muscle receives its peptidergic innervation at different stages of development. A large number of VIPIR processes and a small number of SOM-IR fibers were found at 13 d.i. In contrast, SP- and met-ENK-IR did not appear in the smooth muscle until 17 to $21 \mathrm{~d}$.i. At that time, the greatest number of fibers were immunoreactive for VIP, a smaller number were SP-IR. SOMand met-ENK-IR fibers were the least abundant. With respect to its intrinsic neurons, we find that the duodenum matures from the serosal to the mucosal surface. 
The immunoreactivity appears first in the myenteric plexus, followed by the submucosal plexus, and finally the mucosal plexus. Immunoreactivity appeared between 17 and 21 d.i. in the mucosal plexus, which contained many VIP-IR and smaller numbers of SP-IR fibers.

The distributions of the four peptides in the gut of the hatched chick have been described in previous publications (Alumets et al., 1978; Sundler et al., 1979; Brodin et al., 1981) and are consistent with our results. More recently, Saffrey et al. (1982) studied the changes in distribution of VIP, SOM, met-ENK, and neurotensin in gut from 11- to 21-day-old chick embryos and from young and adult chickens. Whereas our studies have focused on the foregut in early developmental stages, their observations extended to the entire gastrointestinal tract of older embryos and chicks. For ages where our studies overlapped, we find, in general, our results in agreement with theirs.

Conclusion. This study has focused on the early appearance of peptides in the developing chick gut. We have presented evidence that these peptides appear early in ontogeny. In addition, our results indicate that differences in the distribution of the peptides arise early in development and that these peptides do not follow a common pattern of appearance in the different regions of the foregut.

\section{References}

Allan, I. J., and D. F. Newgreen (1980) The origin and differentiation of enteric neurons of the intestine of the fowl embryo. Am. J. Anat. 157: 137-154.

Alumets, J., R. Hakanson, F. Sundler, and K. J. Chang (1978) Leu-enkephalin-like material in nerves and enterochromaffin cells in the gut. Histochemistry 56: 187-196.

Anderton, B. H., D. Breinburg, M. J. Downes, P. J. Green, B. E. Tomlinson, J. Ulrich, J. N. Wood, and J. Kahn (1982) Monoclonal antibodies show that neurofibrillary tangles and neurofilaments share antigenic determinants. Nature 298: $84-86$.

Bennett, T., and J. L. S. Cobb (1969) Studies on the avian gizzard: The development of the gizzard and its innervation. Z. Zellforsch. Mikrosk. Anat. 98: 599-621.

Brodin, E., J. Alumets, R. Hakanson, S. Leander, and F. Sundler (1981) Immunoreactive substance $P$ in the chicken gut: Distribution, development and possible functional significance. Cell Tissue Res. 216: 455-469.

Burnstock, G. (1981) Neurotransmitters and trophic factors in the autonomic nervous system. J. Physiol. (Lond.) 313: 1-35.

Cochard, P., M. Goldstein, and I. B. Black (1978) Ontogenetic appearance and disappearance of tyrosine hydroxylase and catecholamines in the rat embryo. Proc. Natl. Acad. Sci. U. S. A. 75: 2986-2990.

Coons, A. H. (1958) Fluorescent antibody methods. In General Cytochemical Methods, J. F. Danielli, ed., pp. 399-422, Academic Press, Inc., New York.

Epstein, M. L., D. Sherman, and M. D. Gershon (1980) Development of serotonergic neurons in the chick duodenum. Dev. Biol. 77: 22-40.

Epstein, M. L., I. Lindberg, and J. L. Dahl (1981) Development of enkephalinergic neurons in the gut of the chick. Peptides 2: $271-276$.

Erichsen, J. T., A. Reiner, and H. J. Karten (1982) Co-occurrence of substance P-like and leu-enkephalin-like immunoreactivities in neurons and fibers of avian nervous system. Nature 295: 407-410.
Fontaine-Perus, J., M. Chanconie, J. M. Polak, and N. M. LeDouarin (1981) Origin and development of VIP and substance-P containing neurons in the embryonic avian gut. Histochemistry 71: 313-323.

Furness, J. B., and M. Costa (1980) Types of nerves in the enteric nervous system. Neuroscience 5: 1-20.

Furness, J. B., M. Costa, I. J. Llewellyn-Smith, R. Franco, and A. J. Wilson (1981) Polarity and projections of peptidecontaining neurons in the guinea pig small intestine. In Cellular Basis of Chemical Messengers in the Digestive System, M. I. Grossman, M. A. B. Brazier, and J. Lechago, eds., pp. 201-214, Academic Press, Inc., New York.

Gershon, M. D. (1981) The enteric nervous system. Annu. Rev. Neurosci. 4: 227-272.

Gershon, M. D., M. L. Epstein, and L. Hegstrand (1980) Colonization of the chick gut by progenitors of enteric serotonergic neurons: Distribution, differentiation and maturation within the gut. Dev. Biol. 77: 41-51.

Gintzler, A. R. (1980) Substance P involvement in the expression of gut dependence on opiates. Brain Res. 182: 224-228.

Hokfelt, T., O. Johansson, A. Ljungdahl, J. Lundberg, and M. Schultzberg (1980) Peptidergic neurones. Nature (Lond.) 284: 515-521.

Holzer, P., P. C. Emson, L. L. Iverson, and D. F. Sharman (1981) Regional differences in the response to substance $P$ of the longitudinal muscle and the concentration of substance $\mathrm{P}$ in the digestive tract of the guinea pig. Neuroscience 7. 1433-1441.

Jessen, K. R., J. M. Polak, S. Van Noorden, S. R. Bloom, and G. Burnstock (1980) Peptide-containing neurons connect the two ganglionated plexuses of the enteric nervous system. Nature 283: 391-393.

LeDourarin, N. M. (1980) The ontogeny of the neural crest in avian embryo chimeras. Nature 286: 663-669.

LeDouarin, N. M., and M. A. Teillet (1973) The migration of neural crest cells to the wall of the digestive tract in avian embryo. J. Embryol. Exp. Morphol. 30: 31-48.

Malmfors, G., S. Leander, E. Brodin, R. Hakanson, T. Holmin, and F. Sundler (1981) Peptide-containing neurons intrinsic to the gut wall. Cell Tissue Res. 214: 225-238.

Patterson, P. H. (1978) Environmental determination of autonomic neurotransmitter function. Annu. Rev. Neurosci. 1: 117.

Polak, J. M., and S. R. Bloom (1981) Distribution, origin, and pathology of the gut peptidergic innervation. In Cellular Basis of Chemical Messengers in the Digestive System, M. I. Grossman, M. A. B. Brazier, and J. Lechago, eds., pp. 267-282, Academic Press, Inc., New York.

Potter, D. D., E. J. Furshpan, and S. C. Landis (1983) Transmitter status in cultured rat sympathetic neurons: Plasticity and multiple function. Fed. Proc. 42: 1626-1632.

Saffrey, M. J., J. M. Polak, and G. Burnstock (1982) Distribution of vasoactive intestinal polypeptide-, substance $\mathrm{P}$-, enkephalin-, and neurotensin-like immunoreactive nerves in the chicken gut during development. Neuroscience 7: 279293.

Schultzberg, M., C. F. Dreyfus, M. D. Gershon, T. Hokfelt, R. P. Elde, G. Nilsson, S. Said, and M. Goldstein (1978) VIP-, enkephalin-, substance P- and somatostatin-like immunoreactivity in neurons intrinsic to the intestine: Immunohistochemical evidence from organotypic tissue cultures. Brain Res. 155: 239-248.

Schultzberg, M., T. Hokfelt, T. Nilsson, L. Terenius, J. F. Rehfeld, M. Brown, M. Goldstein, and S. Said (1980) Distribution of peptide- and catecholamine-containing neurons in the gastrointestinal tract of the rat and guinea-pig: Immunohistochemical studies with antisera to substance-P, vasoactive intestinal polypeptide, enkephalins, somatostatin, gas- 
trin/cholecystokinin, neurotensin and dopamine beta-hydroxylase. Neuroscience 5: 689-744.

Smith, J., P. Cochard, and N. M. LeDouarin (1977) Development of choline acetyltransferase and cholinesterase activities in enteric ganglia derived from presumptive adrenergic and cholinergic levels of the neural crest. Cell Differ. 6: 199216.

Sternberger, L. A. (1979) Immunocytochemistry, John Wiley \& Sons, Inc., New York.

Sundler, F., J. Alumets, J. Fahrenkrug, R. Hakanson, and 0. B. Schaffalitzky de Muckadell (1979) Cellular localization and ontogeny of immunoreactive vasoactive intestinal poly- peptide (VIP) in the chicken gut. Cell Tissue Res. 196: 193201.

Swaab, D. F., C. W. Pool, and F. Nijveldt (1975) Immunofluorescence of vasopressin and oxytocin in the rat hypothalamoneurohypophyseal system. J. Neural Transm. 36: 195-215.

Teiteleman, G., T. H. Joh, and D. J. Reis (1978) Transient expression of a noradrenergic phenotype in cells of the rat embryonic gut. Brain Res. 158: 229-234.

Teitelman, G., M. D. Gershon, T. P. Rothman, T. H. Joh, and D. J. Reis (1981) Proliferation and distribution of cells that transiently express a catecholaminergic phenotype during development in mice and rats. Dev. Biol. 86: 348-355. 